\title{
EDUCORETAX
}

Volume 1 No. 1, Maret 2021

\section{UPAYA HUKUM WAJIB PAJAK TERHADAP SURAT KEPUTUSAN PENGURANGAN ATAU PENGHAPUSAN SANKSI ADMINISTRASI}

\author{
Heru Saputro*1), Benny Setiawan²) \\ 1) 2301190139_heru@pknstan.ac.id, Politeknik Keuangan Negara STAN \\ 2) benny.setiawan@pknstan.ac.id, Politeknik Keuangan Negara STAN
}

\begin{abstract}
The Decree on the Reduction or Elimination of Administrative Sanctions issued due to the taxpayer's ignorance is a decision related to the implementation of tax decisions that have the potentially to cause disputes. This is because there are no clear boundaries regarding the criteria for error. As a result, there are opportunities for interested parties to interpret subjectively (Huda, 2015). If the taxpayer feels that The Decree on the Reduction or Elimination of Administrative Sanctions issued by the DGT is not appropriate, then the taxpayer can file a legal action in the form of a lawsuit to the Tax Court. What is interesting in the lawsuit process is how the panel of judges decides on tax dispute cases that arise due to unclear criteria in a rule, in this case related to taxpayer ignorance. In addition, the decision issued by the Tax Court must be able to provide a sense of justice to taxpayers considering the purpose of establishing the Tax Court is to create justice and legal certainty in the settlement of tax disputes. Keywords: Tax, Decree on the Reduction or Elimination of Administrative Sanctions, Tax legal remedies, Tax $\underline{\text { Court }}$
\end{abstract}

\begin{abstract}
Abstrak
Surat Keputusan Pengurangan atau Penghapusan Sanksi Administrasi yang diterbitkan akibat adanya kekhilafan wajib pajak merupakan keputusan berkaitan dengan pelaksanaan keputusan perpajakan yang berpotensi terjadi sengketa. Hal itu disebabkan karena tidak adanya batasan-batasan yang jelas mengenai kriteria kekhilafan yang diatur di dalam sebuah aturan. Akibatnya terbuka peluang bagi pihak-pihak yang berkepentingan yaitu wajib pajak dan petugas pajak untuk menafsirkan secara subjektif (Huda, 2015). Jika wajib pajak merasa bahwa surat keputusan pengurangan atau penghapusan sanksi administrasi yang diterbitkan DJP tidak tepat, maka wajib pajak dapat mengajukan upaya hukum berupa gugatan ke Pengadilan Pajak. Yang menarik dalam proses gugatan tersebut adalah mengenai bagaimana majelis hakim memutuskan perkara sengketa pajak yang timbul karena ketidakjelasan kriteria di dalam sebuah aturan, dalam kasus ini yaitu terkait kekhilafan wajib pajak. Selain itu, putusan yang diterbitkan oleh Pengadilan Pajak harus dapat memberikan rasa keadilan kepada wajib pajak mengingat tujuan pembentukan Pengadilan Pajak adalah untuk menciptakan keadilan dan kepastian hukum dalam penyelesaian sengketa pajak.

Kata Kunci: Pajak, Surat Keputusan Pengurangan atau Penghapusan Sanksi Administrasi, Upaya hukum perpajakan, Pengadilan Pajak
\end{abstract}

\section{PENDAHULUAN}

Pajak semakin krusial bagi pembangunan nasional. Konklusi ini tampak pada keputusan pemerintah untuk menaikkan target penerimaan pajak setiap tahunnya (Mustaqiem, 2014). Jika kita lihat pada Anggaran Pendapatan dan Belanja Negara (APBN) 2020, target penerimaan pajak mencapai 1.865,7 triliun rupiah. Jumlah ini memberikan proporsi $83 \%$ dari total rencana pendapatan negara. Meskipun realisasi penerimaan pajak tahun 2019 tidak mencapai target yang ditetapkan, pemerintah tetap menaikkan target penerimaan pajak sebesar 18,5\% dari tahun sebelumnya. Hal tersebut menunjukan bahwa negara ini sangat bergantung dengan pajak untuk membiayai semua pengeluaran termasuk pengeluaran pembangunan.

Sebagai konsekuensi dari pentingnya pajak, pemerintah selalu berupaya untuk melakukan evaluasi-evaluasi terhadap sistem perpajakan dan melakukan penyempurnaan kebijakan agar dapat mengumpulkan penerimaan pajak yang lebih optimal. Salah satu bentuk penyempurnaan tersebut adalah reformasi perpajakan. Reformasi perpajakan di Indonesia telah dimulai sejak tahun 1983 dengan mengubah sistem pemungutan yang semula Official Assesment System, di mana pajak dihitung dan ditetapkan oleh petugas pajak, menjadi Self Assesment System, yang memberikan kepercayaan secara penuh kepada wajib pajak untuk menghitung, memperhitungkan, membayar dan melaporkan pajak yang terutang. Tujuan penerapan Self 


\section{EDUCORETAX}

Volume 1 No. 1, Maret 2021

Assesment System adalah untuk meningkatkan kepatuhan sukarela, efisiensi administrasi pajak, dan meningkatkan keadilan bagi wajib pajak (Liyana, 2019).

Terdapat kelemahan dari penerapan sistem Self Assesment yaitu wajib pajak rentan untuk tidak melaksanakan kewajibannya, baik kewajiban formal maupun kewajiban material. Siregar (2015) mengungkapkan bahwa secara alamiah wajib pajak akan berupaya menetapkan nilai pajak sekecil-kecilnnya. Pernyataan senada juga diungkapkan Tarjo \& Kusumawati (2006), yang mengatakan Self Assesment System dalam praktiknya sulit berjalan sesuai dengan yang diharapkan atau bahkan disalahgunakan. Untuk itu, Direktorat Jenderal Pajak (DJP) diberikan wewenang berdasarkan undang-undang untuk melaksanakan pengawasan dan penegakan hukum. Di antara wewenang DJP adalah menerbitkan Surat Ketetapan Pajak (SKP) maupun Surat Tagihan Pajak (STP). Pengawasan dan penegakan hukum tersebut dimaksudkan agar sistem yang ada dapat berjalan dengan baik sebagaimana mestinya.

Di lain sisi, untuk menciptakan rasa keadilan bagi wajib pajak, DJP mengatur mengenai hak-hak yang dapat dimanfaatkan oleh wajib pajak terkait dengan penerbitan Surat Ketetapan Pajak maupun Surat Tagihan Pajak. Salah satu hak yang bisa dimanfaatkan adalah pengurangan atau penghapusan sanksi administrasi. Pasal 36 ayat (1) huruf a Undang-Undang nomor 16 tahun 2009 tentang KUP mengatur bahwa Direktorat Jenderal Pajak karena jabatan atau atas permohonan wajib pajak dapat mengurangkan atau menghapuskan sanksi administrasi berupa bunga, denda, dan kenaikan yang terutang sesuai dengan ketentuan peraturan perundangundangan perpajakan dalam hal sanksi tersebut dikenakan karena kekhilafan wajib pajak atau bukan karena kesalahannya. Penjelasan di pasal 36 ayat (1) UU nomor 16 tahun 2000 tentang perubahan kedua UU KUP, secara implisit menyebutkan bahwa aturan tersebut dibuat pada dasarnya adalah untuk memberikan perlindungan kepada wajib pajak yang tidak melaksanakan kewajibannya akibat tidak memahami peraturan perpajakan atau kesalahan yang disebabkan bukan karena wajib pajak itu sendiri (Huda, 2015). Wajib pajak yang ingin memanfaatkan pengurangan atau penghapusan sanksi administrasi harus mengajukan permohonan secara tertulis kepada DJP. DJP berdasarkan permohonan wajib pajak, melakukan penelitian untuk menentukan apakah unsur kekhilafan atau bukan karena kesalahan wajib pajak terpenuhi. Atas hasil penelitian yang telah dilakukan, DJP akan menerbitkan surat keputusan pengurangan atau penghapusan sanksi administrasi yang berisi menolak ataupun mengabulkan permohonan wajib pajak.

Dalam meneliti permohonan wajib pajak, DJP mengacu pada Peraturan Menteri Keuangan nomor 8/PMK.03/2013 tentang Tata Cara Pengurangan atau Penghapusan Sanksi Administrasi dan Pengurangan atau Pembatalan Surat Ketetapan Pajak atau Surat Tagihan Pajak. Akan tetapi tidak diaturnya batasan-batasan yang jelas mengenai kriteria khilaf di dalam peraturan tersebut, mengakibatkan terbukanya peluang bagi pihak-pihak yang berkepentingan untuk menafsirkan secara subjektif (Huda, 2015). Hal itulah yang sering menimbulkan sengketa pajak terhadap surat keputusan pengurangan atau penghapusan sanksi administrasi. Sengketa pajak disebabkan karena adanya perbedaan pandangan dalam menafsirkan suatu aturan antara wajib pajak dengan petugas pajak. Berdasarkan ketentuan pasal 1 angka 5 UU no. 14 tahun 2002 tentang Pengadilan Pajak, yang dimaksut dengan sengketa pajak adalah sengketa yang timbul dalam bidang perpajakan antara wajib pajak atau penanggung pajak dengan pejabat yang berwenang sebagai akibat dikeluarkannya keputusan yang dapat diajukan banding atau gugatan kepada pengadilan pajak berdasarkan peraturan perundang-undangan perpajakan, termasuk gugatan atas pelaksanaan penagihan berdasarkan Undang-undang Penagihan Pajak dengan Surat Paksa.

Jika wajib pajak merasa bahwa surat keputusan pengurangan atau penghapusan sanksi administrasi yang diterbitkan DJP tidak tepat, maka wajib pajak dapat mengajukan upaya hukum berupa gugatan. Gugatan diajukan secara tertulis kepada Pengadilan Pajak. Yang 


\section{EDUCORETAX}

Volume 1 No. 1, Maret 2021

menarik dalam proses gugatan tersebut adalah mengenai bagaimana majelis hakim memutuskan perkara sengketa pajak yang timbul karena ketidakjelasan kriteria di dalam sebuah aturan, dalam kasus ini yaitu terkait kekhilafan wajib pajak. Dalam penelitiannya, Wahyudi (2020) mengatakan bahwa Pengadilan Pajak dalam memutus sengketa pajak telah memberikan keadilan substantif kepada para pencari keadilan yaitu wajib pajak. Fakta tersebut menggambarkan putusan yang dihasilkan Pengadilan Pajak justru tidak cenderung memenangkan pemerintah dalam hal ini DJP, namun benar-benar objektif berdasarkan fakta persidangan dan ketetuan hukum yang berlaku. Tetapi apakah benar keadilan itu juga berlaku ketika majelis hakim dihadapkan pada sengketa pajak akibat perbedaan penafsiran khilaf antara wajib pajak dengan DJP. Hal tersebut penting mengingat tujuan pembentukan Pengadilan Pajak adalah untuk menciptakan keadilan dan kepastian hukum dalam penyelesaian sengketa pajak. Adapun tujuan penelitian ini adalah mengetahui penyebab-penyebab timbulnya sengketa pajak antara wajib pajak dengan Direktorat Jenderal Pajak terkait unsur kekhilafan wajib pajak, mengetahui landasan pemikiran yang digunakan oleh majelis hakim dalam memutuskan perkara di dalam sengketa yang disebabkan kekhilafan wajib pajak, dan meninjau apakah Pengadilan Pajak telah dapat memberikan keadilan dan kepastian hukum kepada wajib pajak terhadap sengketa pajak yang timbul dikarenakan kekhilafan wajib pajak.

Selanjutnya, tujuan penelitian ini yaitu: (1) Untuk mengetahui penyebab-penyebab timbulnya sengketa pajak antara wajib pajak dengan Direktorat Jenderal Pajak terkait unsur kekhilafan wajib pajak; (2) Untuk mengetahui landasan pemikiran yang digunakan oleh majelis hakim dalam memutuskan perkara di dalam sengketa yang disebabkan kekhilafan wajib pajak; (3) Untuk meninjau apakah Pengadilan Pajak telah dapat memberikan keadilan dan kepastian hukum kepada wajib pajak terhadap sengketa pajak yang timbul dikarenakan kekhilafan wajib pajak.

\section{KAJIAN PUSTAKA}

\section{Pentingnya Pajak Bagi Negara}

Pajak adalah kontribusi wajib kepada negara yang bersifat memaksa berdasarkan undangundang untuk keperluan negara bagi kemakmuran rakyat. Berbeda dengan retribusi, masyarakat yang membayar pajak tidak langsung mendapatkan imbalan pada saat itu juga, tetapi masyarakat akan merasakan manfaatnya secara tidak lansgung misalnya fasilitas pendidikan, kesehatan, infrastruktur, dan subsidi-subsidi yang diberikan oleh pemerintah. Pajak merupakan hak yang dimiliki oleh negara dikarenakan dalam menyelenggarakan pemerintahan negara membutuhkan dana untuk menutup biaya-biaya yang dikeluarkan. Ketentuan mengenai pemungutan pajak tercantum di dalam UUD 1945 yaitu pasal 23A yang menyebutkan setiap pungutan pajak yang dilaksanakan oleh pemerintah harus dituangkan di dalam undang-undang.

Pajak merupakan sumber pendapatan negara terbesar. Sebagai gambaran, pada tahun 2021 proporsi penerimaan perpajakan di APBN mencapai sekitar $82 \%$ dari total target pendapatan negara. Dari segi proporsi, tidak terdapat kenaikan yang signifikan dibanding APBN tahun sebelumnya, tetapi dari segi nilainya, target penerimaan pajak naik sebesar 40 triliun rupiah dari target penerimaan pajak tahun 2020. Hal itu semakin menegaskan posisi pajak bagi kehidupan bernegara. Pajak menjadi komponen terpenting untuk menunjang pembangunan di Indonesia. Kegagalan pemerintah dalam mengumpulkan penerimaan pajak dapat menghambat proses pembangunan yang sedang digalakkan. Sebaliknya, keberhasilan pemerintah dalam memungut pajak membuat program pembangunan yang sudah direncanakan dapat terlaksana sebagaimana mestinya. Untuk itu, pemerintah dalam hal ini Direktorat Jenderal Pajak (DJP) harus mengambil langkah-langkah yang efektif dan efisien agar dapat memaksimalkan penerimaan pajak demi tercapainya tujuan bernegara. 


\section{EDUCORETAX}

Volume 1 No. 1, Maret 2021

Reformasi perpajakan yang dimulai pada tahun 1983 merupakan salah satu bentuk upaya pemerintah dalam menyempurnakan sistem perpajakan di Indonesia. Perubahan besar yang diambil dalam reformasi perpajakan tahun 1983 adalah dengan mengubah sistem pemungutan pajak yang semula Official Assesment System, di mana pajak dihitung dan ditetapkan oleh petugas pajak, menjadi Self Assesment System, yang memberikan kepercayaan secara penuh kepada wajib pajak untuk menghitung, memperhitungkan, membayar dan melaporkan pajak yang terutang. Tujuan penerapan Self Assesment System adalah untuk meningkatkan kepatuhan sukarela, efisiensi administrasi pajak, dan meningkatkan keadilan bagi wajib pajak (Liyana, 2019). Selain mengubah sistem pemungutan pajak, pemerintah juga semakin memperhatikan terkait hak-hak wajib pajak selaku pembayar pajak. Hak wajib pajak pada dasarnya dibuat untuk memberikan perlindungan terhadap kepentingan wajib pajak. Kepedulian pemerintah atas hak wajib pajak diharapkan dapat memperbaiki perspektif wajib pajak yang bisa meningkatkan kepatuhan sukarela wajib pajak.

\section{Pengertian Sengketa Pajak}

Menurut Setiawan \& Cahyady (2020) sengketa pajak terjadi karena adanya ketidaksamaan persepsi atau perbedaan pendapat antara wajib pajak dengan petugas pajak. Hal itu senada dengan yang dikemukakan oleh Mustaqiem (2014) yang menyebutkan bahwa sengketa pajak timbul karena adanya persepsi terhadap hukum yang berbeda.

Pendapat lainnya diungkapkan oleh Widiastuti (2015) yang mengatakan bahwa sengketa pajak juga termasuk bagian dari sengketa dalam lingkup hukum administrasi. Opini tersebut didasari atas ruang lingkup hukum pajak yang masuk dalam ruang lingkup hukum publik. Jika berlandaskan opini di atas maka pengertian sengketa pajak akan sejalan dengan pengertian sengketa administrasi. Menurut Peraturan Mahkamah Agung No. 6 Tahun 2018 tentang Pedoman Penyelesaian Sengketa Administrasi Pemerintahan Setelah Menempuh Upaya Administratif, pasal 1 angka 5 menyebutkan bahwa sengketa administrasi pemerintahan adalah sengketa yang timbul dalam bidang administrasi pemerintahan antara warga masyarakat dengan badan dan/atau pejabat pemerintahan sebagai akibat dikeluarkan keputusan dan/atau tindakan pemerintahan berdasarkan hukum publik. Dari beberapa definisi sengketa yang diambil dari KBBI dan beberapa aturan di atas, secara garis besar dapat disimpulkan terdapat dua komponen penyebab timbulnya sengketa, yaitu pertama adanya perbedaan pendapat dan yang kedua adanya keputusan yang diterbitkan.

\section{Sekilas tentang Pengurangan atau Penghapusan Sanksi Administrasi Perpajakan}

Pajak tidak hanya tentang aturan-aturan yang harus dilaksanakan oleh wajib pajak dalam melaksanakan kewajibannya, melainkan terdapat pula hak-hak yang dapat dimanfaatkan oleh wajib pajak. Pemberian hak-hak kepada wajib pajak sangatlah penting dalam upaya meningkatkan efektifitas pemungutan pajak sehingga dapat terkumpulnya penerimaan yang lebih optimal. Dengan adanya hak-hak wajib pajak yang diakui dan mendapat perlindungan hukum di dalam sistem pajak di Indonesia, akan membentuk persepsi keadilan yang dirasakan oleh wajib pajak. Organisation for Economic Cooperation and Development (OECD) di dalam laporannya mengatakan wajib pajak yang menyadari hak-haknya, mengharapkan agar hak tersebut terpenuhi, dan jika mereka mendapat perlakuan yang adil atas hak-haknya, maka wajib pajak akan lebih bersedia patuh terhadap ketentuan perpajakan (OECD, 1999). Persepsi keadilan yang dirasakan oleh wajib pajak akan berdampak pada kepatuhan sukarela wajib pajak dalam membayar pajaknya. Untuk itu pemerintah wajib memperhatikan hak-hak wajib pajak agar dapat meningkatkan kepatuhan wajib pajak demi penerimaan negara.

Sengketa pajak terkait dengan Surat keputusan pengurangan atau penghapusan sanksi administrasi biasanya disebabkan adanya perbedaan interpretasi terhadap penentuan kekhilafan 


\section{EDUCORETAX}

Volume 1 No. 1, Maret 2021

antara wajib pajak dan petugas pajak. Pengurangan atau penghapusan sanksi administrasi adalah salah satu hak yang sering dimanfaatkan oleh wajib pajak. Sebagai gambaran, pada tahun 2017 jumlah permohonan pengurangan atau penghapusan sanksi administrasi di Kanwil DJP Jawa Tengah I sebanyak 3.578 permohonan. Jumlah tersebut naik menjadi 9.380 permohonan pada tahun 2018 (Dewi \& Ma'ruf, 2019). Dengan banyaknya jumlah permohonan, semakin tinggi pula kemungkinan terjadinya sengketa pajak. Untuk itu diperlukan kepastian hukum yang jelas sebagai pedoman bagi pihak-pihak terkait.

\section{Unsur Kekhilafan di dalam Pajak}

Istilah kekhilafan umumnya hanya ada di hukum pidana yang mengatur tentang pelanggaran-pelanggaran dan kejahatan-kejahatan terhadap kepentingan umum. Sedangkan dalam hukum administrasi istilah kekhilafan pada umumnya tidak digunakan dikarenakan adanya asas fiksi hukum yang menganggap setiap orang mengetahui peraturan-peraturan yang telah diundangkan. Tetapi hal itu berbeda pada hukum pajak yang merupakan bagian dari hukum administrasi. Banyaknya aturan dan kompleksibilitas yang sering kali cukup sulit bagi kebanyakan masyarakat untuk memahami ketentuan perpajakan membuat asas fiksi hukum tidak diberlakukan di hukum pajak di Amerika (Strauss, 2015).

Jika dikaitkan dengan hukum pidana, kekhilafan di dalam peraturan perpajakan memiliki cakupan yang lebih sempit. Hukum pidana mengenal dua bentuk kekhilafan yaitu mistake of fact dan mistake of law. Pengertian tentang mistake of fact dan mistake of law dapat dipahami berdasarkan ilustrasi yang dibuat oleh Winnings (1993), ia mengatakan

A mistake of law occurs, for example, when one person shoots and kills another, believing that murder is not a crime. 8 A mistake of fact, on the other hand, occurs if that same person knows that murder is illegal, but pulls the trigger anyway under the mistaken belief that the gun is not loaded.

Selanjutnya Winnings juga memberikan ilustrasi mistake of fact dan mistake of law jika dikaitkan dengan kasus perpajakan.

When a taxpayer miscalculates her income, she makes a mistake offact, but if she believes,

for instance, that the Internal Revenue Code does not tax capital gains, she operates under a mistake of law.

Menurut Winnings, secara umum di dalam hukum pidana, mistake of law tidak dapat menghindarkan seseorang dari jeratan hukum akibat adanya asas fiksi hukum, yaitu asas yang menganggap bahwa setiap masyarakat mengetahui hukum yang berlaku dan menanggung risiko atas perbuatannya yang melanggar hukum. Sebaliknya, mistake of fact dapat dijadikan pembelaan yang kuat untuk meloloskan seseorang dari sanksi hukum. Berbeda di dalam hukum pajak, menurutnya perbedaan mistake tersebut tidaklah berarti, karena kedua jenis mistake dapat membebaskan wajib pajak dari sanksi yang seharusnya diberikan. Kegagalan hukum pajak dalam membedakan antara mistake of fact dan mistake of law menunjukkan penyimpangan yang signifikan dari asas hukum tradisional (Winings, 1993).

Pendapat Dr. Chairul Huda, S.H., M.H justru berbeda, menurutnya kekhilafan di dalam peraturan perpajakan di Indonesia lebih tertuju pada mistake of law. Sedangkan mistake of fact bukan merupakan kekhilafan. Kekeliruan ketika menghitung penghasilan sebagai dasar pengenaan pajak, tidak dapat disebut sebagai bentuk kekhilafan. Termasuk keterlambatanketerlambatan yang dilakukan oleh wajib pajak, misalnya keterlambatan penyampaian Surat Pemberitahuan (SPT) dan keterlambatan penyetoran pajak, semuanya tidak dipandang sebagai kekhilafan. Kekhilafan dalam perpajakan terjadi misalnya akibat diterbitkannya peraturan baru ataupun perubahan peraturan yang sudah ada yang menyebabkan wajib pajak salah dalam 


\section{EDUCORETAX}

Volume 1 No. 1, Maret 2021

menjalankan kewajiban perpajakannya. Dalam hal ini, kekhilafan tersebut dapat dimaafkan oleh Direktorat Jenderal Pajak (Huda, 2015).

Permasalahan yang patut menjadi perhatian adalah pembuktian unsur kekhilafan.. Kekhilafan menjadi hal yang tidak mudah untuk ditentukan apakah unsur tersebut telah terpenuhi atau tidak. Menurut Dr. Chairul Huda, S.H., M.H. di dalam artikelnya mengatakan bahwa kekhilafan adalah sesuatu yang cukup sukar untuk ditentukan batas-batasnya. Sering kali penggunaan istilah ini di dalam peraturan, membuka subjektifitas dari pihak-pihak yang berkepentingan, termasuk wajib pajak dan petugas pajak (Huda, 2015). Permasalahan tersebut bertambah ketika tidak ada aturan yang secara jelas mengatur mengenai kriteria-kriteria untuk menentukan kekhilafan wajib pajak. Akibatnya, sangat memungkinkan terjadinya sengketa pajak karena perbedaan penafsiran kekhilafan antara petugas pajak dengan wajib pajak yang tercantum di dalam surat keputusan pengurangan atau penghapusan sanksi administrasi yang telah diterbitkan.

Jika kita amati sejarahnya, kekhilafan atau ignorance sudah menjadi isu yang diperdebatkan di sistem perpajakan Amerika sejak kurang dari satu abad yang lalu. Terdapat dua kasus pelanggaran pajak akibat adanya unsur kekhilafan yang berpengaruh besar terhadap peraturan perpajakan di Amerika. Kasus pelanggaran yang terjadi pada tahun 1933 dalam kasus Murdock dan kasus kedua terjadi pada tahun 1991 pada kasus Cheek. Dalam menyelesaikan kasus Murdock dan Cheek, cara yang dilakukan pengadilan pajak di Amerika adalah dengan melakukan pengujian terhadap unsur kesengajaan (willfully). Dikutip dari jurnal yang ditulis Strauss (2015), terhadap kasus Murdock, pengadilan pajak memutuskan untuk membebaskan Murdock dari tuntutan hukuman. Argumen yang digunakan majelis hakim adalah, yang pertama kekhilafan terhadap aturan dengan niat jujur dan dapat dipercaya (bona fide) dapat dimaafkan. Argumen kedua mengimplikasikan bahwa kekhilafan terhadap aturan yang dilakukan berdasarkan alasan yang masuk akal (reasonable) juga dapat dimaafkan.

Pada kasus Cheek pengadilan pajak menginstrusikan kepada juri sidang bahwa kesalahpahaman terhadap aturan dengan alasan yang masuk akal dan i'tikad baik akan meniadakan kesengajaan dan merupakan pembelaan yang valid bagi Cheek. Tetapi pada saat itu, The District Court memutuskan bahwa opini Cheek yang menganggap upah bukan termasuk pendapatan dan hukum pajak merupakan hukum inkonstitusional, tidak mencerminkan i'tikad baik. Selain itu, terdapat argumen yang menyatakan bahwa kejujuran yang disertai dengan alasan yang tidak masuk akal bukanlah pembelaan dan tidak meniadakan unsur kesengajaan. Berdasarkan pendapat di atas, majelis hakim memutuskan bahwa Cheek bersalah atas kedua tuduhan. Cheek kemudian pengajukan peninjauan kembali dan menghasilkan putusan yang berbeda. Mahkamah Agung Amerika Serikat membatalkan putusan pengadilan terdahulu dan membebaskan Cheek dari tuntutan hukum. Argumen yang digunakan majelis adalah pelanggaran yang dilakukan Cheek disebabkan karena adanya kesalahan interpretasi (misinterpretation) walapun alasan yang dikemukakan tidak masuk akal (Strauss, 2015).

Berdasarkan dua kasus di Amerika tersebut, dapat diambil kesimpulan bahwa dalam memeriksa kekhilafan wajib pajak, hal yang harus dilakukan adalah menguji adanya unsur kesengajaan wajib pajak. Wajib pajak yang ternyata terdapat unsur kesengajaan dalam melakukan pelanggaran pajak, maka fasilitas pengurangan atau penghapusan sanksi administrasi tidak dapat diberikan. Untuk menguji unsur kesengajaan wajib pajak, tentunya menjadi beban pembuktian yang harus dibuktikan oleh majelis hakim saat penyelesaian sengketa pajak di pengadilan pajak. Beberapa indikator yang dapat digunakan berdasarkan dua kasus di atas antara lain niat jujur waib pajak dan dapat dipercaya, alasan yang masuk akal, i'tikad baik wajib pajak, dan adanya kesalahan interpretasi wajib pajak terhadap aturan. 


\section{EDUCORETAX}

Volume 1 No. 1, Maret 2021

\section{Fungsi dan Kedudukan Pengadilan Pajak}

Semakin meningkatnya jumlah wajib pajak dan tingkat pemahaman mereka dalam melaksanakan hak dan kewajiban perpajakannya, semakin besar pula kemungkinan timbulnya sengketa pajak. Data statistik berkas sengketa di pengadilan pajak menunjukan pada tahun 2018 jumlah berkas sengketa yang melibatkan DJP sebesar 7.813, tahun berikutnya mengalami kenaikan menjadi 12.882, dan kemudian tahun 2020 tercatat 14.660 berkas sengketa. Untuk itu, diperlukan lembaga peradilan independen yang dapat menyelesaikan sengketa pajak secara adil dengan prosedur dan proses yang cepat, murah, dan sederhana. Secara eksplisit fungsi Pengadilan Pajak tertuang dalam Pasal 2 Undang-Undang Nomor 14 Tahun 2002 tentang Pengadilan Pajak yang menyebutkan Pengadilan Pajak adalah badan peradilan yang melaksanakan kekuasaan kehakiman bagi wajib pajak atau penanggung pajak yang mencari keadilan terhadap sengketa pajak. Jika dicermati, pasal 2 juga mengandung arti bahwa pengadilan pajak merupakan instrumen untuk melindungi kepentingan wajib pajak. Dalam konteks ini, Pengadilan pajak menjalankan fungsi perlindungan hukum bagi wajib pajak atau penanggung pajak. Hal itu didasarkan pada kenyataan bahwa yang menjadi objek sengketa adalah tindakan atau keputusan Direktorat Jenderal Pajak (DJP) yang dipermasalahkan oleh wajib pajak (Pudyatmoko, 2020). Fungsi Pengadilan Pajak sejalan dengan fungsi badan peradilan sebagaimana disebutkan dalam pasal 24 ayat (1) UUD 1945 (Perubahan Ketiga) yaitu guna menegakkan hukum dan keadilan bagi masyarakat dalam hal ini wajib pajak (Rumadan, 2012).

Keberadaan lembaga peradilan di suatu negara adalah prasyarat negara hukum. Setiap sengketa yang terjadi harus diselesaikan sesuai dengan hukum (due process of law) dan melalui lembaga peradilan yang independen (Wahyudi, 2020). Penyelenggaraan peradilan guna menegakkan hukum dan keadilan merupakan tugas kekuasaan kehakiman. Pasal 18 UndangUndang nomor 48 tahun 2009 tentang kekuasaan kehakiman menyebutkan kekuasaan kehakiman dilakukan oleh Mahkamah Agung dan badan peradilan yang berada di bawahnya. Badan peradilan yang berada di bawah Mahkamah Agung meliputi badan peradilan dalam lingkungan peradilan umum, peradilan agama, peradilan militer, dan peradilan tata usaha negara. Sebagai lembaga yang berada di bawah Mahkamah Agung, pengadilan pajak tentunya harus masuk ke dalam salah satu lingkungan peradilan yang ada (Pudyatmoko, 2020).

\section{Keadilan dalam Proses Peradilan Pajak}

Persoalan keadilan dalam proses peradilan merupakan isu utama yang kerap menimbulkan pergulatan bagi pihak-pihak yang berkepentingan. Hal itu dapat dipahami mengingat tujuan dibentuknya lembaga peradilan adalah untuk mewujudkan keadilan dan kepastian hukum bagi pihak yang bersengketa. Pengadilan pajak sebagai pihak yudikatif di dalam sistem perpajakan di Indonesia juga tidak terlepas akan isu tersebut. Pengadilan pajak memiliki peranan penting untuk melindungi kepentingan wajib pajak dalam mencari keadilan terhadap proses pelaksanaan kewajiban perpajakannya.

Beberapa penelitian terdahulu mengungkapkan bahwa pengadilan pajak masih belum dapat menciptakan keadilan bagi wajib pajak. Salah satu pendapat dikemukakan oleh Yahya Harahap yang mempermasalahkan dualisme pembinaan di tubuh pengadilan pajak. Sebagaimana diatur di dalam Undang-Undang Nomor 14 tahun 2002 pasal 5 bahwa pembinaan teknis peradilan bagi pengadilan pajak dilakukan oleh Mahkamah Agung sedangkan pembinaan organisasi, administrasi, dan keuangan dilakukan oleh Departemen Keuangan. Meskipun pasal 5 ayat (3) menyebutkan pembinaan tersebut tidak boleh mengurangi kebebasan hakim dalam memeriksa dan memutus sengketa pajak, namum dualisme pembinaan sperti itu perlu dicermati karena mengandung kekeliruan dan ketidakbenaran. Alasannya adalah dengan menempatkan badan 


\section{EDUCORETAX}

Volume 1 No. 1, Maret 2021

peradilan di bawah eksekutif, meskipun hanya dari segi organisasional, administrasi, dan finansial, merupakan sebuah pengakuan secara yuridis bahwa badan peradilan tersebut terletak di bawah struktur organisasi departemen yang bersangkutan dalam hal ini Departemen Keuangan. Lebih lanjut, simbol tersebut dapat memberi peringatan kepada para hakim mengenai batas otonomi kebebasan mereka, bahwa dalam menjalankan fungsi dan kewenangan peradilan berada di bawah kontrol pihak departemen. Oleh karena itu, pengaruh simbol di dalamnya menimbulkan efek politik dan psikologis yang sangat kuat terhadap kemandirian dan kebebasan hakim dalam memutuskan perkara sengketa pajak. Alasan selanjutnya yaitu sistem dualisme yang ada menghambat program pengawasan dan pembinaan yang komprehensif dan integratif (Harahap, 1997).

Hal senada juga diungkapkan oleh Ismail Rumadan dalam jurnal penelitiannya. Dari pengaturan dualisme pembinaan dapat terlihat bahwa pengadilan pajak hanya merupakan rezim dari sistem hukum pajak, bukan merupakan rezim Undang-Undang Kekuasaan Kehakiman. Eksistensi pengadilan pajak seperti ini sangat berpotensi terjadinya campur tangan pihak pemerintah (eksekutif) terhadap independensi hakim dalam memutus perkara sengketa pajak. Alasan yang dikemukakan bahwa pengadilan pajak bukan bagian dari kekuasaan kehakiman disebabkan karena dalam proses penyelesaian sengketa pajak tidak ada upaya banding maupun upaya hukum kasasi sebagai bentuk pengawasan secara teknis yudisial oleh Mahkamah Agung terhadap putusan pengadilan pajak. Hal itu merujuk pada pasal 33 Undang-Undang Nomor 14 tahun 2002 yang menyebutkan pengadilan pajak merupakan Pengadilan tingkat pertama dan terakhir dalam memeriksa dan memutus sengketa pajak. Secara teoritis, setiap pengadilan dalam keempat lingkungan peradilan mempunyai atribusi vertikal, yaitu wewenang yang bersifat bulat dan melekat dari suatu jenis pengadilan terhadap jenis pengadilan lain, yang mempunyai kedudukan lebih tinggi. Hal ini berkenaan dengan adanya tuntutan untuk memperolah keadilan yang lebih mendekati kesempurnaan. Upaya dalam mendekati kesempurnaan keadilan dapat dicapai melalui pemeriksaan sengketa secara bertingkat berdasarkan sistem peradilan dengan MA sebagai puncaknya. Dengan adanya piramidal peradilan, maka terbuka pemeriksaan sengketa yang didasarkan pada kedudukan fungsi peradilan secara hirarkis dalam pengadilan bertingkat. Bedasarkan penjelasan tersebut dapat disimpulkan bahwa layaknya proses peradilan seharusnya terdapat upaya hukum banding, kasasi, dan peninjauan kembali sebagai langkah dalam mewujudkan keadilan. Namun dalam kasus sengketa pajak, upaya hukum yang ada hanyalah peninjauan kembali. Hal itu tentu tidak dapat menjamin adanya kepastian dan keadilan hukum bagi wajib pajak (Rumadan, 2012).

Pendapat lain justru dikemukakan oleh Tri Hidayat Wahyudi yang mengatakan bahwa pengadilan pajak telah dapat memberikan keadilan substantif kepada wajib pajak. Hal itu tercermin dari putusan-putusan yang diterbitkan oleh pengadilan pajak. Data menunjukkan pada tahun 2016 dan 2017 mayoritas putusan majelis yaitu sebanyak 54\% menyatakan mengabulkan permohonan yang diajukan oleh wajib pajak atau penanggung pajak. Fakta di atas menggambarkan meskipun pengadilan pajak dalam hal administrasi dan organisasi di bawah Kementerian Keuangan, namun putusan yang dihasilkan tidak cenderung memenangkan Direktorat Jenderal Pajak. Di sisi lain, jika melihat hasil pengujian terhadap putusan pengadilan pajak yang diajukan peninjauan kembali, secara keseluruhan pada periode 2013 sampai dengan tahun 2018 putusan Mahkamah Agung yang dalam amar putusannya menyatakan menolak permohonan peninjauan kembali sebesar $84,65 \%$. Hal ini berarti bahwa sebesar $84,65 \%$ putusan pengadilan pajak dipertahankan oleh Mahkamah Agung. Kondisi tersebut menggambarkan pengadilan pajak selaku pihak yudikatif telah dapat memberikan keadilan atau setidaknya memberikan harapan kepada pencari keadilan dalam hal terjadi sengketa perpajakan (Wahyudi, 2020). 


\section{EDUCORETAX}

Volume 1 No. 1, Maret 2021

\section{METODE}

Dalam penelitian ini penulis menggunakan metode analisis data kualitatif untuk memperoleh pemahaman tentang suatu masalah atau fenomena yang terjadi (tujuan ekplorasi). Pendekatan yang digunakan dalam metode ini adalah pendekatan analisis konten (content analysis). Analisis konten merupakan sebuah teknik penelitian untuk menyimpulkan makna teks melalui prosedur tertentu yang dapat diandalkan (reliable) dan dapat direplikasi (replicable) (Krippendorff, 2004). Berdasarkan definisi tersebut secara jelas terlihat bahwa tujuan dari analisis konten adalah untuk menemukan makna atau pola yang terjadi pada objek penelitian. Identifikasi makna atau pola dilakukan melalui proses coding yaitu dengan mengelompokkan data yang memiliki arti yang serupa. Langkah coding adalah dengan memberi label atau kode pada setiap unit data. Unit data dapat berupa kalimat, kata, maupun paragraf yang terdapat pada objek data yang dianalisis. Coding merupakan bagian dari proses reduksi data. Ada dua pendekatan yang bisa dilakukan dalam proses coding, yang pertama adalah coding dilakukan secara deduktif di mana penulis sudah menyiapkan daftar kode sebelum melakukan coding atas data kualitatif. Pendekatan yang kedua adalah pendekatan induktif, di mana kode muncul berdasarkan unit data yang tidak disiapkan sebelumnya dan belum dikaitkan dengan teori ketika proses coding berlangsung. Penelitian ini sendiri lebih menitikberatkan pada pendekatan coding secara induktif agar dapat memperoleh gambaran makna yang lebih aktual. Menurut Thomas (2006), hasil dari analisis secara induktif mempunyai keunggulan dikarenakan dapat meringkas data mentah yang kompleks dengan cara mengembangkan kategori ke dalam sebuah kerangka berfikir. Analsisis induktif merupakan prosedur untuk menemukan makna berdasarkan interpretasi penulis melalui pembacaan secara detail terhadap teks di dalam objek penelitian. Hasil dari coding kemudian dianalisa agar dapat diambil kesimpulannya secara menyeluruh.

Teknik pengumpulan data dilakukan dengan cara dokumentasi. Dokumentasi adalah salah satu metode dalam pengumpulan data kualitatif dengan cara mengumpulkan dokumen yang digunakan sebagai bahan di dalam penelitian. Dokumentasi tidak hanya dilakukan terhadap data berupa tulisan saja, tetapi gambar, buku, iklan, monografi, dll juga termasuk dokumen yang bisa dijadikan bahan penelitian. Dokumentasi merupakan catatan atas suatu peristiwa yang sudah terjadi (Sugiyono, 2010). Myers (2009) mengelompokkan dokumen ke dalam beberapa jenis antara lain personal dokumen (by individuals), dokumen publik (produce for public consumption), dokumen organisasi (internal document), media masa, dan dokumen virtual. (Myers, 2019). Di dalam penelitian ini, jenis dokumen yang dipakai adalah dokumen publik berupa putusan pengadilan pajak. Pemilihan dokumentasi sebagai metode pengumpulan data mempunyai kelebihan dan kekurangan. Kelebihan dokumentasi antara lain biaya yang relatif murah dan cepat diakses, memberikan riwayat peristiwa atau fenomena yang terlihat dan dapat dilacak, menyediakan detail yang penting untuk membantu referensi silang, dan berguna dalam melengkapi data lain dari penelitian lapangan. Di sisi lain terdapat kelemahan di dalam dokumentasi di karenakan kesulitan dalam menilai kualitas dokumen berupa keaslian, kredibilitas, keterwakilan, dan makna. Tetapi kelemahan tersebut setidaknya dapat berkurang jika dokumen yang digunakan berupa dokumen publik yang diterbitkan oleh instansi pemerintah resmi seperti putusan pengadilan.

Data yang digunakan di dalam penelitian ini berupa data sekunder. Data sekunder adalah data yang sebelumya telah ada yang dikumpulkan oleh penulis sebagai bahan dalam menganalisis kesimpulan (Prabandari, 2020). Data sekunder yang digunakan berupa sampel putusan pengadilan pajak atas gugatan wajib pajak terhadap surat keputusan pengurangan atau penghapusan sanksi administrasi. Pemilihan sampel putusan dilakukan dengan teknik sampling judgement dikarenakan data putusan yang terdapat pada website 


\section{EDUCORETAX}

Volume 1 No. 1, Maret 2021

http://www.setpp.kemenkeu.go.id tidak memiliki indeks yang spesifik sehingga penulis mengunduh secara acak terhadap putusan-putusan yang diterbitkan pada tahun 2020 dan 2019 . Kemudian penulis melakukan identifikasi secara satu-persatu terhadap putusan-putusan yang sudah diunduh untuk mencari putusan atas sengketa gugatan terhadap surat keputusan pengurangan atau penghapusan sanksi administrasi yang pokok sengketanya disebabkan karena kekhilafan wajib pajak. Jumlah sampel yang digunakan berjumlah lima putusan agar dapat melihat pola yang terjadi sehingga dapat diperoleh kesimpulan sesuai tujuan penelitian.

\section{HASIL DAN PEMBAHASAN}

\section{Penyebab Timbulnya Sengketa Pajak Terkait Unsur Kekhilafan Wajib Pajak}

Sengketa pajak dapat terjadi karena adanya perbedaan interpretasi sebuah aturan antara wajib pajak dan fiskus, maka tentunya masing-masing pihak mempunyai pendapatnya sendiri terkait dengan hal yang disengketakan. Oleh sebab itu, ketika mengajukan gugatan ke pengadilan pajak, wajib pajak harus menyertakan penjelasan dan alasan mengajukan gugatan. Sebaliknya, DJP yang menjadi pihak tergugat akan dimintai pendapatnya melalui surat tanggapan gugatan. Berdasarkan dua komponen tersebut, yaitu alasan wajib pajak mengajukan gugatan dan surat tanggapan yang diberikan oleh DJP, dapat diketahui faktor-faktor utama penyebab terjadinya sengketa pajak. Dengan menggunakan metode analisis konten, hasil yang diperoleh adalah sebagai berikut.

Tabel 0.1 Coding sheet Alasan Pengajuan Gugatan Wajib Pajak

\begin{tabular}{|c|c|c|}
\hline Kategori & Coding & Unit Data \\
\hline \multirow[t]{5}{*}{ Jenis Kesalahan } & $\begin{array}{ll}\text { Tidak melakukan } \\
\text { pembayaran PPh Final }\end{array}$ & $\begin{array}{l}\text { "Penggugat tidak melakukan pembayaran PPh } \\
\text { Final" }\end{array}$ \\
\hline & $\begin{array}{l}\text { Tidak menjalankan } \\
\text { kewajiban PPN }\end{array}$ & $\begin{array}{l}\text { "Penggugat tidak menjalankan kewajiban } \\
P P N^{\prime}\end{array}$ \\
\hline & $\begin{array}{l}\text { WP tidak membetulkan } \\
\text { SPT PPN }\end{array}$ & $\begin{array}{l}\text { "Penggugat belum melakukan pembetulan } \\
\text { SPT PPN karena tidak mengetahui } \\
\text { kompensasi lebih bayar Tahun } 2015 \text { tidak } \\
\text { boleh dipakai" }\end{array}$ \\
\hline & $\begin{array}{l}\text { Kesalahan penerapan } \\
\text { aturan }\end{array}$ & $\begin{array}{l}\text { "SPT Tahunan PPh Badan } 2015 \text { dan } 2016 \\
\text { karena seharusnya dilaporkan berdasarkan } \\
\text { PMK No 107/PMK.010/2015 yang berlaku } 9 \\
\text { Agustus } 2015 \text { dengan Perhitungan Tidak } \\
\text { Final" }\end{array}$ \\
\hline & $\begin{array}{l}\text { Belum membayar PPN } \\
\text { JLN }\end{array}$ & $\begin{array}{l}\text { "Terdapat PPN JLN terutang untuk Masa } \\
\text { Pajak Juni Tahun } 2014 \text { yang belum dibayar } \\
\text { oleh Penggugat" }\end{array}$ \\
\hline \multirow[t]{3}{*}{$\begin{array}{l}\text { Kurangnya } \\
\text { pengetahuan }\end{array}$} & $\begin{array}{l}\text { WPOP yang tidak } \\
\text { memiliki pengetahuan } \\
\text { perpajakan }\end{array}$ & $\begin{array}{l}\text { "Penggugat merupakan Wajib Pajak pribadi } \\
\text { yang tidak memiliki pengetahuan sama sekali } \\
\text { tentang peraturan perpajakan yang berlaku di } \\
\text { Indonesia" }\end{array}$ \\
\hline & $\begin{array}{l}\text { Ketidakpahaman SDM } \\
\text { dalam menjalankan } \\
\text { administrasi perpajakan }\end{array}$ & $\begin{array}{l}\text { "karena ketidakpahaman dan tidak adanya } \\
\text { SDM yang mampu menjalankan administrasi } \\
\text { perpajakan" }\end{array}$ \\
\hline & $\begin{array}{l}\text { WP tidak mengetahui } \\
\text { konsekuensi } r \text { sebuah } \\
\text { aturan }\end{array}$ & $\begin{array}{l}\text { "Penggugat belum melakukan pembetulan } \\
\text { SPT PPN karena tidak mengetahui } \\
\text { kompensasi lebih bayar Tahun } 2015 \text { tidak } \\
\text { boleh dipakai" }\end{array}$ \\
\hline
\end{tabular}




\section{EDUCORETAX}

Volume 1 No. 1, Maret 2021

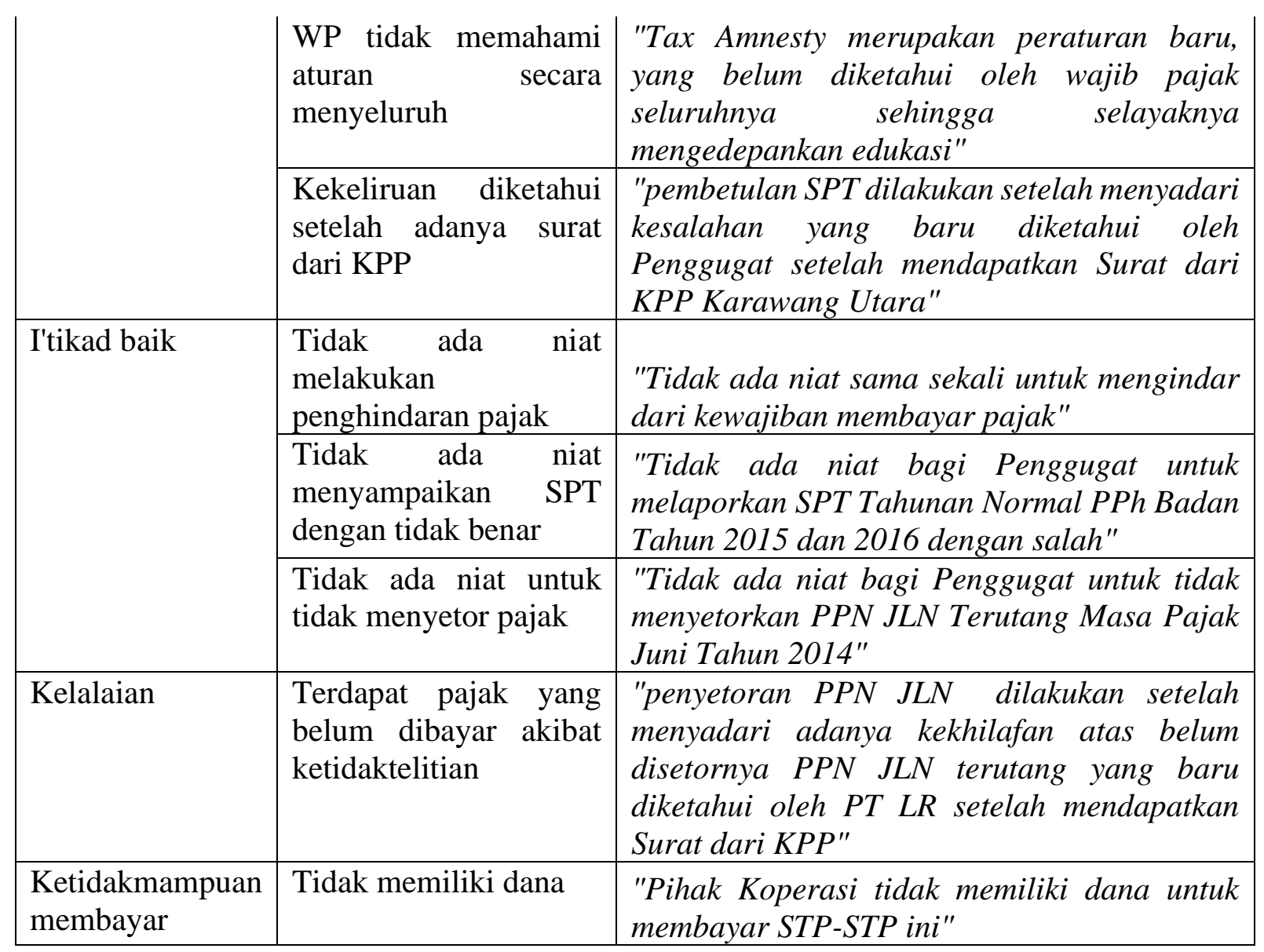

Sumber: Data diolah berdasarkan sampel putusan pengadilan pajak

Dari tabel di atas dapat dilihat bahwa jenis kesalahan yang umumnya terjadi adalah wajib pajak tidak melakukan pembayaran/penyetoran pajak. Diikuti dengan kewajiban pelaporannya. Jika dihubungkan dengan dua jenis kesalahan yaitu mistake of fact dan mistake of law, harus diketahui terlebih dahulu penyebab kesalahan tersebut bisa terjadi. Misalnya pada putusan nomor PUT-001593.99/2020/PP/M.IB tahun 2020 kesalahan awal wajib pajak adalah tidak melakukan pembayaran PPh Final yang disebabkan karena wajib pajak tidak mengetahui bahwa ia harus membayar $\mathrm{PPh}$ final setiap bulan sebesar $1 \%$ sebagaimana diatur dalam dalam Peraturan Menteri Keuangan nomor PMK-107/PMK.011/2013, maka kesalahan tersebut dapat digolongkan sebagai mistake of law. Hal yang sama juga terdapat pada putusan nomor PUT007837.99/2019/PP/M.VB tahun 2020 dan PUT-000133.99/2019/PP/M.IIIA tahun 2019. Pada putusan PUT-007837.99/2019/PP/M.VB wajib pajak koperasi tidak menjalankan kewajiban PPN dikarenakan pengurus koperasi tidak mengetahui bahwa hasil produksinya yang berupa tandan buah segar (TBS) merupakan barang kena pajak, padahal sebelumnya tidak pernah terjadi permasalahan terkait penjualan TBS. Hal ini dikarenakan adanya aturan baru yang memasukkan TBS menjadi barang kena pajak yang belum dipahami oleh pengurus koperasi. Lalu pada putusan PUT-000133.99/2019/PP/M.IIIA, wajib pajak yang menjalankan usaha distributor minyak pelumas melaksanakan kewajiban perpajakannya secara final sesuai aturan sebelumnya, tetapi ternyata terdapat aturan baru yang menyatakan bahwa wajib pajak seharusnya melaksakanan kewajiban perpajakannya dengan ketentuan tarif umum sehingga wajib pajak seharusnya menyetor angsuran PPh pasal 25 tiap bulannya. Ketiga permasalahan tersebut merupakan contoh kesalahan yang termasuk mistake of law yaitu kesalahann yang timbul dikarenakan wajib pajak tidak mengetahui ketentuan perpajakan. Dua putusan lainnya merupakan contoh kesalahan yang disebabkan karena adanya mistake of fact. Pertama pada 


\section{EDUCORETAX}

Volume 1 No. 1, Maret 2021

putusan nomor PUT-003397.99/2019/PP/M.VB tahun 2019 mengenai wajib pajak yang tidak melakukan pembetulan SPT Masa PPN Lebih Bayar dikarenakan wajib pajak tidak berhak memanfaatkan kompensasi kerugian akibat mengikuti program Tax Amnesty sebagaimana diatur dalam pasal 35 PMK nomor 118/PMK.03/2016. Kesalahan tersebut merupakan kesalahan mistake of fact karena pada dasarnya wajib pajak memahami aturan tentang Tax Amnesty dibuktikan dengan wajib pajak mengikuti program tersebut, tetapi karena ketidakcermatannya dalam menjalankan administrasi perpajakan, wajib pajak akhirnya tetap mengkompensasikan kelebihan pembayaran PPN ke masa berikutnya. Sedangkan pada putusan berikutnya nomor PUT-005477.99/2019/PP/M.XXB tahun 2019, wajib pajak tidak menyetor PPN JLN dikarenakan adanya kelalaian, dan baru menyadari setelah diterbitkan surat imbauan dari Kantor Pelayanan Pajak (KPP). Hal ini jelas merupakan mistake of fact karena wajib pajak sebenarnya mengetahui bahwa transaksinya terutang PPN JLN, tetapi karena ketidaktelitian dalam menjalankan administrasinya yang menyebabkan terdapat kewajiban perpajakan yang terlewat atau belum dilaksanakan oleh wajib pajak.

Selain faktor ketidaktahuan tentang peraturan perpajakan, faktor lainnya yang dijadikan indikator oleh wajib pajak bahwa tindakannya merupakan sebuah kekhilafan adalah i'tikad baik dan ketidakmampuan membayar sanksi pajak. I'tikad baik menurut wajib pajak adalah perilaku di mana wajib pajak tidak berniat untuk melakukan pelanggaran dalam menjalankan kewajiban perpajakannya. Sedangkan ketidakmampuan membayar sanksi administrasi disebabkan karena kondisi keuangan wajib pajak yang hanya bisa menutup besaran pokok pajak tetapi tidak dengan sanksi pajaknya. Sehingga secara umum dapat disimpulkan bahwa faktor-faktor yang menentukan kekhilafan menurut pandangan wajib pajak adalah tidak mengetahui peraturan perpajakan, ketidakcermatan dalam menjankan administrasi, i’tikad baik wajib pajak, dan tidak mampu membayar sanksi administrasi perpajakan.

Di sisi lain, pihak tergugat dalam hal ini Direktorat Jenderal Pajak mempunyai argumen yang menjadi dasar atas tidak dikabulkannya surat permohonan pengurangan atau penghapusan sanksi administrasi akibat kekhilafan yang diajukan oleh wajib pajak. Alasan-alasan penyebab kekhilafan menurut wajib pajak sebagaimana disebutkan pada paragraf sebelumnya akan dinilai oleh petugas peneliti untuk menentukan apakah alasan tersebut dapat diterima. Dikarenakan kriteria khilaf tidak diatur secara jelas di dalam peraturan yang menjadi pedoman teknis pengurangan atau penghapusan sanksi administrasi yaitu Peraturan Menteri Keuangan nomor PMK-8/PMK.03/2013, petugas pajak mempunyai argumen tersendiri mengenai faktor-faktor yang menyebabkan tidak terpenuhinya unsur khilaf wajib pajak. Berdasarkan analisis konten di bawah ini, secara umum dapat diketahui beberapa indikator yang dijadikan acuan oleh petugas pajak dalam mengambil keputusan.

Tabel 0.2 Coding Sheet Alasan Penolakan oleh Petugas Pajak

\begin{tabular}{|l|l|l|}
\hline \multicolumn{1}{|c|}{ Kategori } & \multicolumn{1}{|c|}{ Coding } & \multicolumn{1}{|c|}{ Unit Data } \\
\hline Lama WP terdaftar & $\begin{array}{l}\text { WP sudah terdaftar sejak } \\
2010\end{array}$ & $\begin{array}{l}\text { "Bahwa Penggugat telah terdaftar sejak } \\
\text { tanggal 20 Juli 2010" }\end{array}$ \\
\cline { 2 - 3 } & $\begin{array}{l}\text { WP sudah terdaftar sejak } \\
2004\end{array}$ & $\begin{array}{l}\text { "Penggugat sudah terdaftar sebagai } \\
\text { Wajib Pajak sejak tanggal 25 Mei 2004" }\end{array}$ \\
\cline { 2 - 3 } & $\begin{array}{l}\text { WP terdaftar PKP sejak "bahwa PT Luxindo Raya dikukuhkan } \\
1989\end{array}$ & $\begin{array}{l}\text { sebagai Pengusaha Kena Pajak pada } \\
\text { tanggal 27 Juli 1989" }\end{array}$ \\
\cline { 2 - 3 } & $\begin{array}{l}\text { WP telah terdaftar sejak } \\
2008\end{array}$ & $\begin{array}{l}\text { "Penggugat terdaftar di KPP Pratama } \\
\text { Sampit pada tangal 26 Maret 2008 dan } \\
\text { dikukuhkan sebagai Pengusaha Kena } \\
\text { Pajakpada tanggal 05 November 2014" }\end{array}$ \\
\hline
\end{tabular}




\section{EDUCORETAX}

Volume 1 No. 1, Maret 2021

\begin{tabular}{|c|c|c|}
\hline \multirow[t]{3}{*}{ Pemberian Edukasi } & 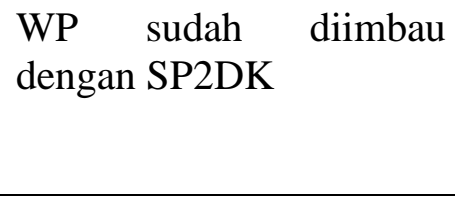 & $\begin{array}{l}\text { "Bahwa terhadap Penggugat telah } \\
\text { dilakukan himbauan/SP2DKtahun pajak } \\
2016 \quad \text { s.d. 2018 oleh Account } \\
\text { Representative" }\end{array}$ \\
\hline & $\begin{array}{lr}\text { KPP sudah melakukan } \\
\text { pembinaan } & \text { dengan } \\
\text { SP2DK } & \\
\end{array}$ & $\begin{array}{l}\text { "Berdasarkan penelitian, terhadap } \\
\text { Penggugat telah dilakukan pembinaan } \\
\text { melalui SP } 2 D K^{2}\end{array}$ \\
\hline & $\begin{array}{l}\text { WP sudah diimbau } \\
\text { dengan SP2DK }\end{array}$ & $\begin{array}{l}\text { "Account Representative telah melakukan } \\
\text { himbauan pertama pada tanggal 08 Maret } \\
2017 \text { dan himbauan kedua dengan } \\
\text { SP } 2 D K-3306 A V P J .22 / K P .02 / 2018 \\
\text { tanggal } 14 \text { Februari 2018" }\end{array}$ \\
\hline \multirow[t]{2}{*}{$\begin{array}{l}\text { Pemanfaatan } \\
\text { insentif perpajakan }\end{array}$} & $\begin{array}{l}\text { WP mengikuti program } \\
\text { Tax Amnesty }\end{array}$ & $\begin{array}{l}\text { "Bahwa Penggugat telah mengikuti } \\
\text { Pengampunan Pajak/Tax Amnesty" }\end{array}$ \\
\hline & $\begin{array}{l}\text { WP mengikuti program } \\
\text { Tax Amnesty }\end{array}$ & $\begin{array}{l}\text { "Sebagai pihak yang telah mengikuti } \\
\text { program Amnesti Pajak seharusnya } \\
\text { mengetahui hak dan kewajiban yang } \\
\text { diatur dalam } \\
\text { Pengampunan Pajak dan ketentuan } \\
\text { pelaksanaannya" }\end{array}$ \\
\hline \multirow[t]{2}{*}{$\begin{array}{l}\text { Penggunaan jasa } \\
\text { konsultan }\end{array}$} & $\begin{array}{lr}\text { WP } & \text { mempunyai } \\
\text { kemampuan } & \text { untuk } \\
\text { menggunakan } & \text { jasa } \\
\text { konsultan } & \end{array}$ & $\begin{array}{l}\text { "Bahwa Pengguat mempunyai } \\
\text { kemampuan ekonomis untuk meminta jasa } \\
\text { konsultan pajak maupun kuasa pajak } \\
\text { dalam rangka melaksanakan hak dan } \\
\text { kewajiban perpajakan" }\end{array}$ \\
\hline & $\begin{array}{l}\text { WP menggunakan jasa } \\
\text { konsultan pajak }\end{array}$ & $\begin{array}{l}\text { "Penggugat sudah menggunakan jasa } \\
\text { konsultan pajak, yaitu Kantor Konsultan } \\
\text { Pajak Hasibuan, Bawazier, dan Pramono } \\
\text { sejak tahun } 2012 \text { sampai dengan } \\
\text { sekarang" }\end{array}$ \\
\hline \multirow[t]{2}{*}{ Usia peraturan } & $\begin{array}{l}\text { Terdapat rentang waktu } \\
\text { yang panjang untuk } \\
\text { memahami peraturan }\end{array}$ & $\begin{array}{l}\text { "Peraturan Menteri Keuangan Nomor } \\
\text { 107/PMK.010/2015 diundangkan pada } \\
\text { tanggal 09 Juni 2015, Penggugat } \\
\text { menyampaikan SPT Tahunan PPh Badan } \\
\text { Tahun Pajak } 2015 \text { tanggal 28 April 2016" }\end{array}$ \\
\hline & $\begin{array}{l}\text { Peraturan merupakan } \\
\text { aturan yang sudah lama }\end{array}$ & $\begin{array}{l}\text { "peraturan tentang pengenaan sanksi } \\
\text { administrasi, baik berupa bunga, } \\
\text { kenaikan maupun denda, dalam surat } \\
\text { ketetapan pajak kurang bayar bukan } \\
\text { merupakan peraturan yang baru berlaku" }\end{array}$ \\
\hline \multirow[t]{2}{*}{$\begin{array}{l}\text { WP tidak } \\
\text { kooperatif }\end{array}$} & $\begin{array}{l}\text { WP tidak merespon Surat } \\
\text { Permontaan Data }\end{array}$ & $\begin{array}{l}\text { "namun Wajib Pajak tidak memberikan } \\
\text { jawaban atas permintaan penjelasan" }\end{array}$ \\
\hline & $\begin{array}{l}\text { WP tidak memberikan } \\
\text { keterangan dan informasi } \\
\text { terkait sengketa }\end{array}$ & $\begin{array}{l}\text { "Wajib Pajak tidak meminjamkan buku, } \\
\text { catatan, data dan informasi terkait materi } \\
\text { sengketa yang diajukan keberatan" }\end{array}$ \\
\hline $\begin{array}{l}\text { Historis } \\
\text { pelaksanaan }\end{array}$ & $\begin{array}{l}\text { WP melaporkan SPT } \\
\text { Masa PPN }\end{array}$ & $\begin{array}{l}\text { "Dibuktikan dengan adanya data } \\
\text { pelaporan SPT Masa PPN berdasarkan } \\
\text { SIDJP" }\end{array}$ \\
\hline
\end{tabular}




\section{EDUCORETAX}

Volume 1 No. 1, Maret 2021

\begin{tabular}{|l|l|l|}
$\begin{array}{l}\text { kewajiban } \\
\text { perpajakan }\end{array}$ & $\begin{array}{l}\text { WP pernah menerbitkan } \\
\text { faktur pajak }\end{array}$ & $\begin{array}{l}\text { "Penggugat sudah pernah menerbitkan } \\
\text { Faktur Pajak pada tanggal 28 November } \\
\text { 2014 dan 30 Desember 2014" }\end{array}$ \\
\hline
\end{tabular}

Sumber: Data diolah berdasarkan sampel putusan pengadilan pajak

Indikator pertama yang paling sering diperhatikan adalah berapa lama penggugat tersebut terdaftar sebagai wajib pajak ataupun pengusaha kena pajak (PKP). Dari lima sampel yang dipilih, empat di antaranya terdapat penjelasan yang menyatakan bahwa wajib pajak telah terdaftar sejak beberapa tahun sehingga menjadi salah satu alasan untuk menolak unsur kekhilafan yang diajukan wajib pajak. Indikator selanjutnya adalah terkait pemberian edukasi. Petugas pajak berdasarkan keterangan yang ada akan melihat apakah sudah pernah dilakukan edukasi dari Account Representative maupun dari Kantor Pelayanan Pajak (KPP) terdaftar. Jika faktanya menunjukkan bahwa wajib pajak sudah pernah diberikan edukasi, baik itu melalui sosialisasi, kunjungan (visit), atau surat imbauan, wajib pajak tersebut dianggap sudah mengetahui tentang aturan perpajakan sehingga alasan kekhilafan wajib pajak tidak dapat diterima. Indikator selanjutnya yang juga diperhatikan adalah mengenai penggunaan jasa konsultan. Wajib pajak yang menggunakan jasa konsultan dalam menjalankan kewajiban perpajakannya sudah selayaknya mengetahui aturan perpajakan dikarenakan salah satu persyaratan sebagai konsultan pajak adalah memahami ketentuan perpajakan. Hal lain yang juga diperhatikan oleh petugas pajak dalam menilai kekhilafan wajib pajak adalah berapa lama usia peraturan terkait objek pajak yang disengketakan telah ada. Kemudian historis pelaksanaan kewajiban perpajakan yang dilakukan oleh wajib pajak dengan melihat data pada sistem informasi DJP. Lalu terkait insentif pajak yang dimanfaatkan oleh wajib pajak misalnya Tax Amnesty. Terakhir yaitu terkait sikap kooperatif wajib pajak dalam hal terdapat permintaan data dan atau keterangan yang diterbitkan oleh KPP.

\section{Landasan Pemikiran Majelis Hakim dalam Memutus Perkara Sengketa Pajak terkait Unsur Kekhilafan Wajib Pajak}

Porses penyelesaian gugatan atas keputusan pengurangan atau penghapusan sanksi administrasi, sesuai ketentuan dilaksanakan melalui pemeriksaan dengan acara biasa, kecuali terdapat hal-hal tertentu sebagaimana diatur dalam pasal 66 Undang-Undang Pengadilan Pajak yang mengharuskan persidangan dilakukan menggunakan pemeriksaan dengan acara cepat. Di dalam pemeriksaan dengan acara biasa, ketua pengadilan pajak menunjuk majelis yang terdiri dari tiga orang hakim yang terdiri dari satu hakim ketua dan sisanya sebagai hakim anggota. Majelis mempunyai kewenangan untuk menetapkan hasil keputusan atas sengketa yang terjadi. Dalam rangka mempertimbangkan keputusan yang akan dibuat, majelis hakim harus melaksanakan penilaian pembuktian. Penilaian tersebut haruslah berdasarkan peraturan perundang-undangan perpajakan yang berlaku serta berdasarkan keyakinan hakim. Oleh sebab itu, hakim dituntut untuk memiliki pengetahuan perpajakan yang baik, bahkan terkadang juga harus memahami peraturan-peraturan lainnya diluar ketentuan perpajakan agar dapat memberikan keputusan terbaik, yang dapat melindungi kepentingan wajib pajak.

Dalam proses pembuktian atas unsur kekhilafan yang menjadi penyebab sengketa antara wajib pajak dengan petugas pajak, majelis tidak dapat berpegang sepenuhnya terhadap aturan perpajakan yang ada dikarenakan kriteria-kriteria yang mengatur tentang kekhilafan tidak diatur secara jelas di dalam peraturan perpajakan. Untuk kasus ini, penilaian pembuktian berdasarkan apa yang diyakini oleh majelis menjadi berperan penting terhadap hasil keputusan yang akan diterbitkan. Keyakinan tersebut tentunya memiliki landasan pemikiran yang diambil berdasarkan fakta persidangan yang ada. Jika diamati berdasarkan sampel yang telah dipilih, 


\section{EDUCORETAX}

Volume 1 No. 1, Maret 2021

dapat diketahui beberapa hal yang menjadi landasan pemikiran bagi majelis hakim dalam membuat keputusan sebagaimana terlihat pada tabel III.3 di bawah ini.

Tabel 0.3 Coding Sheet Landasan Pemikiran Majelis Hakim

\begin{tabular}{|c|c|c|}
\hline Kategori & Coding & Unit Data \\
\hline $\begin{array}{l}\text { Kesalahan } \\
\text { petugas pajak }\end{array}$ & $\begin{array}{l}\text { Penyelesaian } \mathrm{LB} \\
\text { seharusnya melalui } \\
\text { mekanisme } \\
\text { administrasi }\end{array}$ & $\begin{array}{l}\text { "bahwa Majelis berpendapat, kelebihan } \\
\text { pembayaran seharusnya diselesaikan secara } \\
\text { administrasi dengan menerbitkan Surat Perintah } \\
\text { Pengembalian Kelebihan Pembayaran Pajak atau } \\
\text { melalui mekanisme Pemindahbukuan untuk } \\
\text { membayar hutang pajaklainnya" }\end{array}$ \\
\hline $\begin{array}{l}\text { Kesalahan } \\
\text { petugas pajak }\end{array}$ & $\begin{array}{l}\text { Terdapat unsur } \\
\text { ketidaktelitian } \\
\text { petugas pajak }\end{array}$ & $\begin{array}{l}\text { "bahwa menurut Majelis, adanya pemeriksaan } \\
\text { yang dikenakan pajak berdasarkan ketentuan yang } \\
\text { berbeda dengan himbauan yang diberikan, telah } \\
\text { menunjukkan bahwa sanksi administrasi yang } \\
\text { dikenakan kepada Wajib Pajak diakibatkan karena } \\
\text { ketidaktelitian petugas pajak" }\end{array}$ \\
\hline $\begin{array}{l}\text { I'tikad baik } \\
\text { wajib pajak }\end{array}$ & $\begin{array}{lr}\text { Wajib } & \text { pajak } \\
\text { menunjukkan } & \text { i'tikad } \\
\text { baik } & \end{array}$ & $\begin{array}{l}\text { "bahwa Majelis berpendapat, Penggugat telah } \\
\text { menunjukkan itikad baik dengan mengikuti seluruh } \\
\text { himbauan yang dilakukan Tergugat" }\end{array}$ \\
\hline $\begin{array}{l}\text { Tidak } \\
\text { memahami } \\
\text { peraturan } \\
\text { perpajakan }\end{array}$ & $\begin{array}{l}\text { kekhilafan } \\
\text { Penggugat } \\
\text { disebabkan tidak } \\
\text { memahami peraturan } \\
\text { perpajakan }\end{array}$ & $\begin{array}{l}\text { "bahwa menurut Majelis, adanya tindakan } \\
\text { Penggugat untuk mengikuti himbauan yang } \\
\text { diberikan oleh Tergugat meskipun himbauan } \\
\text { tersebut tidak sesuai dengan ketentuan, } \\
\text { menunjukkan bahwa kekhilafan Penggugat } \\
\text { disebabkan tidak memahami peraturan } \\
\text { perpajakan" }\end{array}$ \\
\hline $\begin{array}{l}\text { Kesesuc } \\
\text { terhada] }\end{array}$ & $\begin{array}{ll}\text { Pengenaan } & \text { sanksi } \\
\text { yang sudah } & \text { sesuai } \\
\text { ketentuan } & \end{array}$ & $\begin{array}{l}\text { "bahwa Majelis berpendapat pengenaan sanksi } \\
\text { administrasi sebagaimana tercantum dalam STP } \\
\text { sudah sesuai ketentuan peraturan perpajakan yang } \\
\text { berlaku" }\end{array}$ \\
\hline $\begin{array}{l}\text { Aturan terkait } \\
\text { merupakan } \\
\text { aturan baru }\end{array}$ & $\begin{array}{l}\text { Adanya peraturan } \\
\text { baru yang perlu } \\
\text { disosialisasikan }\end{array}$ & $\begin{array}{l}\text { "bahwa majelis berpendapat, tahun } 2016 \\
\text { merupakan masa transisi adanya perubahan } \\
\text { peraturan yang dalam pelaksanaannya perlu } \\
\text { waktu untuk mensosialisasikannya agar dipahami } \\
\text { oleh Pengusaha Kena Pajak" }\end{array}$ \\
\hline $\begin{array}{l}\text { Kondisi usaha } \\
\text { wajib pajak }\end{array}$ & $\begin{array}{l}\text { Wajib pajak } \\
\text { merupakan koperasi } \\
\text { dengan skala kecil }\end{array}$ & $\begin{array}{l}\text { "bahwa majelis berpendapat, Penggugat adalah } \\
\text { koperasi yang skala usahanya masih kecil yang } \\
\text { menghimpun petani yang memiliki lahan kebun } \\
\text { sawit terbatas dan lokasinya jauh dari perkotaan } \\
\text { sehingga agak sulit dijangkau" }\end{array}$ \\
\hline $\begin{array}{l}\text { Kondisi usaha } \\
\text { wajib pajak }\end{array}$ & $\begin{array}{l}\text { Sanksi administrasi } \\
\text { dapat mematikan } \\
\text { usaha wajib pajak }\end{array}$ & $\begin{array}{l}\text { "tidak semestinya Penggugat dibebani dengan } \\
\text { sanksi yang justru dapat mematikan usahanya, } \\
\text { bahwa oleh karena itu seharusnya sanksi } \\
\text { administrasi tersebut dapat dihapuskan atau } \\
\text { dikurangkan" }\end{array}$ \\
\hline $\begin{array}{l}\text { Tidak terdapat } \\
\text { unsur sengketa }\end{array}$ & $\begin{array}{l}\text { Tidak mengandung } \\
\text { sengketa }\end{array}$ & $\begin{array}{l}\text { "Majelis berpendapat bahwa Keputusan yang } \\
\text { diterbitkan tergugat telah sesuai sehingga tidak }\end{array}$ \\
\hline
\end{tabular}




\section{EDUCORETAX}

Volume 1 No. 1, Maret 2021

\begin{tabular}{|c|c|c|}
\hline & & $\begin{array}{l}\text { mengandung sengketa, baik yang bersifat } \\
\text { pembuktian maupun yuridis" }\end{array}$ \\
\hline $\begin{array}{l}\text { Kesesuaian } \\
\text { terhadap aturan }\end{array}$ & $\begin{array}{l}\text { Pengenaan sanksi } \\
\text { yang sudah sesuai } \\
\text { ketentuan dan tidak } \\
\text { ada sengketa }\end{array}$ & $\begin{array}{l}\text { "Majelis berpendapat bahwa Majelis tidak } \\
\text { memiliki kewenangan untuk mengurangkan atau } \\
\text { menghapuskan sanksi administrasi yang tercantum } \\
\text { dalam Keputusan Tergugat mengingat pengenaan } \\
\text { sanksi administrasi tersebut sudah sesuai } \\
\text { ketentuan dan tidak ada sengketa" }\end{array}$ \\
\hline $\begin{array}{l}\text { Tidak terdapat } \\
\text { unsur sengketa }\end{array}$ & $\begin{array}{l}\text { Tidak terdapat } \\
\text { sengketa terkait } \\
\text { pengenaan sanksi }\end{array}$ & $\begin{array}{l}\text { "Majelis berpendapat bahwa tidak terdapat } \\
\text { sengketa terkait pengenaan sanksi administrasi } \\
\text { yang tercantum dalam Keputusan yang menjadi } \\
\text { objek gugatan" }\end{array}$ \\
\hline $\begin{array}{l}\text { Kesesuaian } \\
\text { terhadap aturan }\end{array}$ & $\begin{array}{l}\text { Tergugat } \\
\text { mengenakan sanksi } \\
\text { sesuai ketentuan }\end{array}$ & $\begin{array}{l}\text { "Majelis berpendapat Tergugat telah menghitung } \\
\text { sanksi sesuai dengan ketentuan yang berlaku" }\end{array}$ \\
\hline $\begin{array}{l}\text { i'tikad buruk } \\
\text { wajib pajak }\end{array}$ & $\begin{array}{l}\text { Tidak bersedia } \\
\text { menyampaikan data } \\
\text { dan dokumen }\end{array}$ & $\begin{array}{l}\text { "bahwa Tergugat telah meminta dokumen dan data } \\
\text { pendukung untuk menguatkan permohonan } \\
\text { Penggugat namun Penggugat tidak menyampaikan } \\
\text { dokumen dan data pendukung dimaksud" }\end{array}$ \\
\hline $\begin{array}{l}\text { Alasan wajib } \\
\text { pajak tidak } \\
\text { masuk akal }\end{array}$ & $\begin{array}{l}\text { Wajib pajak } \\
\text { menggunakan jasa } \\
\text { konsultan pajak }\end{array}$ & $\begin{array}{l}\text { "Majelis berpendapat bahwa keterlambatan } \\
\text { penyetoran PPh Pasal } 25 \text { akibat ketidaktahuan } \\
\text { Penggugat tidak memiliki dasar yang kuat karena } \\
\text { Penggugat untuk kewajiban perpajakannya sudah } \\
\text { menggunakan jasa konsultan pajak" }\end{array}$ \\
\hline
\end{tabular}

Sumber: Data diolah berdasarkan sampel putusan pengadilan pajak

Berdasarkan tabel di atas terlihat bahwa terdapat beberapa landasan pemikiran yang dipakai oleh majelis dalam memutuskan sengketa gugatan akibat kekhilafan wajib pajak. Pertama terkait dengan keputusan yang mengabulkan gugatan wajib pajak. Dari lima sampel putusan yang digunakan, hanya satu yang mengabulkan seluruhnya gugatan wajib pajak yaitu putusan nomor PUT-001593.99/2020/PP/M.IB tahun 2020. Dalam sampel gugatan ini, majelis hakim pertama memeriksa apakah penerapan sanksi yang diterbitkan kepada wajib pajak sudah sesuai dengan prosedur yang berlaku. Hasilnya terdapat unsur kesalahan petugas pajak sebagimana tercermin pada pendapat manjelis yang menyebutkan "bahwa Majelis berpendapat, kelebihan pembayaran seharusnya diselesaikan secara administrasi dengan menerbitkan Surat Perintah Pengembalian Kelebihan Pembayaran Pajak atau melalui mekanisme Pemindahbukuan untuk membayar hutang pajak lainnya.". Selain itu fakta yang menunjukkan terdapat perbedaan ketentuan di dalam surat imbauan yang diterbitkan dengan hasil pemeriksaan pajak, menunjukkan adanya ketidaktelitian petugas pajak. Pendapat majelis tersebut sudah merupakan alasan yang kuat untuk membatalkan surat keputusan yang diterbitkan oleh DJP dan mengabulkan pengurangan atau penghapusan sanksi administrasi wajib pajak. Hal itu diperkuat lagi dengan i'tikad baik yang ditunjukan oleh wajib pajak yaitu dengan segera menyadari kesalahannya dan melakukan pembayaran atas pokok pajak yang kurang dibayar. Dan juga pendapat majelis yang menyimpulkan bahwa wajib pajak benar-benar tidak memahami ketentuan perpajakan dibuktikan dengan wajib pajak tetap menjalankan kewajiban perpajakan sesuai arahan pada surat imbauan padahal surat imbauan tersebut terdapat kekeliruan penerapan ketentuan perpajakan. Jadi, dapat disimpulkan bahwa landasan pemikiran yang digunakan oleh majelis dalam mengabulkan gugatan wajib pajak di dalam putusan ini yaitu adanya kesalahan 


\section{EDUCORETAX}

Volume 1 No. 1, Maret 2021

petugas pajak, i'tikad baik, dan wajib pajak benar-benar tidak memahami peraturan perpajakan yang berlaku.

Selanjutnya terkait dengan putusan gugatan yang isinya menolak gugatan wajib pajak. Dari lima sampel putusan yang dipilih, empat putusan menghasilkan penolakan terhadap gugatan yang diajukan oleh wajib pajak. Tidak terdapat sampel putusan yang berisi mengabulkan sebagian ataupun menambah pajak yang harus dibayar. Dari empat putusan tersebut, secara umum terdapat kemiripan terkait landasan pemikiran yang digunakan oleh majelis hakim untuk mengambil keputusan. Pertama yaitu putusan nomor PUT-007837.99/2019/PP/M.VB tahun 2020. Dalam memeriksan perkara gugatan ini, terdapat beberapa landasan pemikiran majelis hakim antara lain penerapan sanksi kepada wajib pajak telah sesuai dengan ketentuan perpajakan. Dengan kata lain tidak terdapat unsur kesalahan dari petugas pajak. Di sisi lain majelis juga mengutarakan pendapatnya tentang kondisi usaha wajib yang seharusnya diberikan pengurangan sanksi dikarenakan wajib pajak memiliki skala usaha yang masih kecil dan berlokasi jauh dari perkotaan sehingga sulit mendapatkan sosialisasi perpajakan. Selain itu pengenaan sanksi menurut majelis akan mematikan usaha wajib pajak. Serta aturan terkait merupakan aturan yang masih baru sehingga tahun terjadinya sengketa merupakan masa transisi yang membutuhkan waktu bagi wajib pajak untuk memahaminya secara menyeluruh. Tetapi penilaian majelis tentang kondisi wajib pajak dan aturan yang masih dalam masa transisi tidaklah menjadikan permohonan gugatan dikabulkan. Alasan utama majelis adalah kesesuaian penerapan sanksi terhadap aturan yang berlaku dan telah diakui oleh wajib pajak menunjukan tidak adanya sengketa pajak yang terkandung di dalam kasus ini. Hal itu tercermin di dalam kalimat "Majelis berpendapat bahwa Keputusan yang diterbitkan tergugat telah sesuai sehingga tidak mengandung sengketa, baik yang bersifat pembuktian maupun yuridis". Atas dasar tersebut majelis menolak permohonan gugatan wajib pajak dan mempertahankan Surat Keputusan Pengurangan atau Penghapusan Sanksi Administrasi yang diterbitkan sehingga wajib pajak tetap harus membayar sanksi yang tercantum di dalam Surat Tagihan Pajak.

Putusan nomor PUT-003397.99/2019/PP/M.VB tahun 2019 tentang pokok sengketa yang disebabkan karena wajib pajak diterbitkan SKPKB PPN akibat wajib pajak tidak melakukan pembetulan SPT Masa PPN Lebih Bayar. Atas gugatan yang diajukan wajib pajak ke pengadilan pajak, majelis hakim memutuskan untuk menolak permohonan gugatan wajib pajak. Landasan pemikiran yang digunakan mirip dengan putusan sebelumnya yaitu penerapan sanksi kepada wajib pajak sudah sesuai ketentuan yang berlaku sehingga tidak terdapat unsur sengketa di dalam kasus tersebut.

Sampel putusan selanjutnya yaitu putusan nomor PUT-005477.99/2019/PP/M.XXB tahun 2019 tentang pokok sengketa berupa penerbitan SKPKB PPN Jasa Luar Negeri juga menggunakan landasan pemikiran berupa penilain majelis terhadap kesesuaian pengenaan sanksi berdasarkan aturan yang berlaku. Meskipun wajib pajak berasalan bahwa adanya kekhilafan dalam membayar PPN atas pemanfaatan jasa luar negeri tetapi hal tersebut tidak menjadi dasar yang kuat untuk mengabulkan permohonan gugatan wajib pajak. Apalagi majelis menemukan bahwa wajib pajak mempuyai i'tikad buruk yang terlihat dari wajib pajak tidak bersedia memberikan data dan atau keterangan saat proses penerbitan surat keputusan pengurangan atau penghapusan sanksi administrasi oleh DJP. Akhirnya majelis hakim memutuskan untuk menolak permohonan gugatan wajib pajak dan mengharuskan wajib pajak untuk tetap membayar sanksi sebagaiman tercantum dalam SKPKB.

Putusan selanjutnya merupakan putusan yang terakhir dari lima sampel putusan. Di dalam putusan ini, yaitu putusan nomor PUT-000133.99/2019/PP/M.IIIA tahun 2019. majelis menggunakan landasan pemikiran berupa rasionalitas dari alasan yang dibuat oleh wajib pajak. Dalam kasus ini majelis berpendapat bahwa alasan kekhilafan wajib pajak tidak memiliki dasar 


\section{EDUCORETAX}

Volume 1 No. 1, Maret 2021

yang kuat sebagiamana tercermin di dalam kalimat "Majelis berpendapat bahwa keterlambatan penyetoran PPh Pasal 25 akibat ketidaktahuan Penggugat tidak memiliki dasar yang kuat karena Penggugat untuk kewajiban perpajakannya sudah menggunakan jasa konsultan pajak". Pendapat majelis di atas menjadi masuk akal ketika wajib pajak sudah menggunakan jasa konsultan pajak untuk mengurus segala urusan perpajakannya, maka sudah selayaknya wajib pajak memahami aturan-aturan yang seharusnya digunakan. Oleh sebab itu, majelis memutuskan untuk menolak gugatan wajib pajak.

Dari beberapa pembahasan di atas, secara garis besar dapat disimpulkan bahwa majelis hakim di dalam memutus perkara sengketa pajak yang disebabkan karena kekhilafan wajib pajak, menggunakan landasan pemikiran yang hampir sama di setiap kasusnya. Pertama yaitu majelis hakim akan memeriksa terlebih dahulu apakah pengenaan sanksi kepada wajib pajak sudah sesuai ketentuan atau prosedur yang berlaku. Jika terdapat kesalahan yang dilakukan oleh petugas pajak dalam mengenakan sanksi kepada wajib pajak, hampir pasti majelis hakim akan mengabulkan gugatan yang diajukan wajib pajak seperti halnya putusan nomor PUT001593.99/2020/PP/M.IB. Sedangkan apabila pengenaan sanksi kepada wajib pajak sudah sesuai dengan ketentuan yang berlaku, majelis hakim selanjutnya akan memeriksan apakah terdapat unsur sengketa pajak. Jika tidak terdapat unsur sengketa pajak, majelis akan menolak gugatan wajib pajak dikarenakan tugas dari pengadilan pajak sendiri adalah memutus perkara berupa sengketa pajak. Selanjutnya i'tikad buruk yang ditunjukan oleh wajib pajak di dalam persidangan maupun dalam menjalankan kewajiban perpajakannya juga mempengaruhi keyakinan hakim untuk menolak gugatan wajib pajak. Dan yang terakhir adalah rasionalitas dari alasan yang dikemukakan oleh wajib pajak berpengaruh terhadap hasil putusan majelis hakim. Sebagai contoh di putusan nomor PUT-000133.99/2019/PP/M.IIIA tahun 2019 di mana wajib pajak faktanya sudah menggunakan jasa konsultan pajak sehingga alasan ketidaktahuan terhadap aturan perpajakan sangat tidak masuk akal bagi majelis.

\section{Keadilan dan Kepastian Hukum terhadap Putusan Pengadilan Pajak terkait Unsur Kekhilafan Wajib Pajak}

Sebagai badan peradilan yang melaksanakan kekuasaan kehakiman bagi wajb pajak atau penanggung pajak atas sengketa pajak yang terjadi, pengadilan pajak dituntut agar dapat memberikan keadilan dan kepastian hukum dalam penyelesaian sengketa pajak. Jika dikaitkan dengan Undang-Undang tentang Kekuasaan Kehakiman, keadilan hukum merupakan proses mengadili menurut hukum dengan tidak membeda-bedakan orang. Definisi tersebut selaras dengan teori Adam Smith mengenai asas-asas pemungutan pajak yaitu The Four Maxims. Menurut Adam Smith, salah satu asas pemungutan pajak adalah asas kesamaan dan keadilan (equality and equity) yang dimaksudkan untuk memberikan rasa adil dan merata tanpa ada diskriminasi antara wajib pajak dan petugas pajak (Smith, 1904). Berbicara mengenai keadilan hukum tentunya tidak terlepas dengan kepastian hukum. Kedua unsur tersebut memili kaitan yang erat satu sama lain. Kepastian hukum sendiri menurut Jan Michiel Otto bahwa hakimhakim (peradilan) yang mandiri dan tidak berpihak menerapkan aturan-aturan hukum tersebut secara konsisten sewaktu mereka menyelesaikan sengketa hukum (Sidharta, 2009). Dari pendapat ini secara jelas bahwa konsistensi merupakan unsur utama dalam menciptakan kepastian hukum. Lagi-lagi nilai kepastian hukum di dalam proses peradilan juga termasuk di dalam salah satu asas pemungutan pajak Adam Smith. Asas Kepastian hukum (Certainty) dalam proses pemungutan pajak menurut Adam Smith memiliki arti bahwa semua pungutan pajak harus berdasarkan Undang-Undang. Dengan berlandaskan Undang-Undang, proses pemungutan pajak akan berlaku secara konsisten karena memiliki pedoman dasar yang jelas. Jadi, dapat disimpulkan bahwa dengan menciptakan keadilan dan kepastian hukum dalam 


\section{EDUCORETAX}

Volume 1 No. 1, Maret 2021

proses penyelesaian sengketa pajak, memiliki dampak yang besar terhadap terciptanya asasasas pemungutan pajak yang baik.

Sebelumnya disebutkan di dalam landasan teori bahwa terdapat beberapa pendapat yang menilai tentang keadilan di tubuh pengadilan pajak. Pendapat Yahya Harahap menyatakan bahwa dualisme pembinaan di tubuh pengadilan pajak dapat mempengaruhi otonomi kebebasan majelis hakim dalam memutuskan perkara sengketa pajak. Dikhawatirkan dengan adanya dualisme pembinaan tersebut keputusan majelis cenderung memenangkan kepentingan DJP. Tetapi hal itu secara tidak langsung terpatahkan dengan penelitian yang dilakukan oleh Tri Hidayat Wahyudi yang menyatakan bahwa mayoritas putusan majelis yaitu sebanyak 54\% menyatakan mengabulkan permohonan yang diajukan oleh wajib pajak atau penanggung pajak. Fakta di atas menggambarkan meskipun pengadilan pajak dalam hal administrasi dan organisasi di bawah Kementerian Keuangan, namun putusan yang dihasilkan tidak cenderung memenangkan Direktorat Jenderal Pajak. Pendapat selanjutnya dikemukakan oleh Ismail Ramadhan yang menyatakan bahwa tidak adanya upaya banding maupun upaya hukum kasasi menyebabkan kurang maksimalnya pengawasan yang dilakukan oleh mahkamah agung sehingga sangat memungkinkan terjadinya kekeliruan pengadilan pajak dalam memutuskan sengketa pajak. Tetapi hal tersebut juga terbantah berdasarkan data yang ditunjukan oleh Tri Hidayat Wahyudi yang melihat dari putusan peninjauan kembali sebagai upaya hukum luar biasa dari sengketa pajak. Secara keseluruhan pada periode 2013 sampai dengan tahun 2018 putusan Mahkamah Agung yang dalam amar putusannya menyatakan menolak permohonan peninjauan kembali sebesar 84,65\%. Hal ini berarti bahwa sebesar 84,65\% putusan pengadilan pajak dipertahankan oleh Mahkamah Agung. Kondisi tersebut menunjukan sebagian besar keputusan yang diambil oleh majelis hakim telah sesuai ketentuan hukum baik dari segi formalitas maupun materialitas.

Akan tetapi, menilai keadilan dengan cara melihat jumlah putusan yang mengabulkan atau menolak sangat memungkinkan terjadinya bias. Hal itu akan membuat penilaian hanya berlandaskan kuantitas tetapi mengesampingkan kualitas. Sebagai contoh, misalnya suatu pengadilan menerbitkan keputusan dengan jumlah $60 \%$ mengabulkan permohonan gugatan. Tetapi berdasarkan penilian ulang terhadap sengketa, seharusnya jumlah putusan yang mengabulkan gugatan lebih banyak dari itu, tentunya hal tersebut tidak dapat dikatakan adil karena terdapat kesalahan pengadilan dalam memberikan putusannya. Oleh sebab itu, melihat landasan pemikiran yang digunakan majelis hakim sebagai dasar dalam mengambil putusannya, dapat memberikan padangan yang lebih baik dikarenakan dari segi kualitas juga dapat dinilai apakah majelis hakim telah memberikan keputusannya dengan baik dan benar sehingga terpenuhian keadilan dan kepastian hukum bagi wajib pajak.

Jika dilihat berdasarkan landasan pemikiran yang digunakan majelis hakim dalam menilai sengketa pajak yang disebabkan karena adanya kekhilafan wajib pajak, sebagaimana dibahas pada materi sebelumnya, terdapat hal yang perlu dicermati. Pada putusan nomor PUT007837.99/2019/PP/M.VB dan putusan nomor PUT-003397.99/2019/PP/M.VB disebutkan di dalam pendapat majelis bahwa kesesuaian pengenaan sanksi administrasi kepada wajib pajak terhadap ketentuan perpajakan meniadakan unsur sengketa pajak antara wajib pajak dengan petugas pajak. Padahal jika dilihat berdasarkan substansi upaya hukum terhadap surat keputusan pengurangan atau penghapusasan sanksi administrasi yang diajukan wajib pajak, bahwa wajib pajak berharap agar sanksi administrasi tersebut dapat dihapuskan dikarenakan kesalahan wajib pajak disebabkan karena kekhilafan atau ketidaktahuan akan aturan. Jadi, permasalahannya di sini bukan terkait dengan prosedur ataupun tata cara penerbitan sanksi administrasi yang sesuai/tidak sesuai ketentuan tetapi terkait dengan adanya perbedaan penafsiran kekhilafan antara wajib pajak dengan petugas pajak. Wajib pajak menganggap 


\section{EDUCORETAX}

Volume 1 No. 1, Maret 2021

bahwa kesalahannya benar-benar karena kekhilafan sedangkan petugas pajak menganggap bahwa unsur kekhilafan tersebut tidak terpenuhi sehingga pengurangan atau penghapusan sanksi administrasi tidak dapat diberikan. Atas dasar tersebut seharusnya fokus utama yang harus dinilai dan dibuktikan oleh majelis hakim adalah terkait terpenuhinya unsur kekhilafan atau tidak. Bukan terkait dengan kesesuain pengenaan sanksi terhadap undang-undang perpajakan. Jika pemeriksaan kesesuaian sanksi digunakan untuk melihat apakah ada kesalahan petugas pajak dalam mengenakan sanksi administrasi maka hal itu dapat diterima. Sebagaimana tercermin pada putusan nomor PUT-001593.99/2020/PP/M.IB di mana kesalahan dalam mengenakan sanksi kepada wajib pajak otomatis bahwa permohonan gugatan wajib pajak dikabulkan tanpa harus dilanjutkan dengan menilai unsur kekhilafan wajib pajak.

Di dalam proses penyelesaian sengketa pajak, pengetahuan dan pemahaman Majelis terhadap ketentuan pajak dan pokok sengketa yang terjadi sangat dibutuhkan agar keputusan yang diterbitkan dapat memberikan keadilan bagi wajib pajak. Berdasarkan uraian sebelumnya, dapat dicermati bahwa terdapat misinterpretasi yang dilakukan oleh majelis terkait pokok sengketa yang terjadi yaitu mengenai kekhilafan wajib pajak. Hal itu memberikan dampak yang besar terhadap putusan yang diambil oleh majelis hakim. Adanya misinterpretasi membuat putusan menjadi tidak sesuai dengan pokok sengketa. Akibatnya kepentingan wajib pajak dalam hal memperoleh keadilan terkait penyelesaian sengketa pajak menjadi tidak terpenuhi. Dengan kata lain pengadilan pajak gagal dalam memberikan keadilan terhadap upaya hukum wajib pajak atas surat keputusan pengurangan atau penghapusan sanksi administrasi yang diterbitkan DJP. Kegagalan dalam memberikan keadilan tentunya berbanding lurus dengan kepastian hukum yang juga tidak terpenuhi dikarenakan majelis hakim tidak dapat menjalankan fungsinya dengan baik yaitu dalam melakukan penilaian pembuktian. Oleh sebab itu, pengetahuan dan pemahaman yang dimiliki majelis tidak hanya terhadap aturan perpajakan tetapi juga harus memahami terkait substansi dari pokok sengketa pajak yang sedang ditangani.

\section{PENUTUP}

Terdapat beberapa faktor penyebab timbulnya sengketa pajak antara wajib pajak dengan Direktorat Jenderal Pajak terkait perbedaan penafsiran kekhilafan sebagaimana tercantum pada surat pengajuan gugatan dari wajib pajak dan surat tanggapan yang dibuat oleh DJP. Dari sisi wajib pajak, beberapa faktor yang dijadikan indikasi kekhilafan oleh wajib pajak adalah ketidaktahuan atau ketidakpahaman tentang aturan yang ada,ketidakcermatan dalam menjalankan administrasi perpajakan yang mengakibatkan terlewatnya kewajiban, i.tikad baik yang dimiliki wajib pajak dalam menjalankan kewajiban perpajakannya, dan ketidakmmpuan membayar sanksi perpajakan dikarenkan kondisi keuangan wajib pajak. Sedangkan dari sisi DJP, terdapat faktor-faktor yang digunakan sebagai indikasi untuk menolak permohonan pengurangan atau penghapusan sanksi administrasi wajib pajak yang artinya unsur kekhilafan tidak terpenuhi antara lain berapa lama wajib pajak terdaftar di DJP, riwayat pemberian edukasi ataupun sosialisasi kepada wajib pajak, penggunaan jasa konsultan pajak, historis pelaksanaan kewajiban perpajakannya berdasarkan sistem informasi DJP, dan pemanfaatan insentif perpajakan yang diajukan oleh wajib pajak, serta sikap kooperatifan wajib pajak dalam menjalankan kewajiban perpajakannya.

Majelis hakim setelah mempelajari alasan wajib pajak mengajukan gugatan terhadap surat keputusan pengurangan atau penghapusan sanksi administrasi dan penjelasan yang diberikan tergugat dalam hal ini DJP, melakukan penilaian pembuktian untuk mengambil keputusan. Penilaian yan dilakukan majelis hakim haruslah berdasarkan peraturan perundang-undangan perpajakan yang berlaku serta berdasarkan keyakinan hakim. Tetapi ketika memeriksa sengketa pajak yang disebabkan perbedaan penafsiran kekhilafan antara wajib pajak dengan DJP, majelis 


\section{EDUCORETAX}

Volume 1 No. 1, Maret 2021

hakim tidak dapat berpegang sepenuhnya terhadap aturan perpajakan yang ada dikarenakan kriteria-kriteria yang mengatur tentang kekhilafan tidak diatur secara jelas di dalam peraturan perpajakan. Untuk itu, terdapat beberapa landasan pemikiran yang sering kali digunakan oleh majelis hakim antara lain Pertama yaitu majelis hakim akan memeriksa terlebih dahulu apakah pengenaan sanksi kepada wajib pajak sudah sesuai ketentuan atau prosedur yang berlaku. Jika terdapat kesalahan yang dilakukan oleh petugas pajak dalam mengenakan sanksi kepada wajib pajak, hampir pasti majelis hakim akan mengabulkan gugatan yang diajukan wajib pajak. selanjutnya apabila pengenaan sanksi kepada wajib pajak sudah sesuai dengan ketentuan yang berlaku, majelis hakim kemudian memeriksan apakah terdapat unsur sengketa pajak. Jika tidak terdapat unsur sengketa pajak, majelis akan menolak gugatan wajib pajak dikarenakan tugas dari pengadilan pajak sendiri adalah memutus perkara berupa sengketa pajak. Lalu i’tikad buruk yang ditunjukan oleh wajib pajak di dalam persidangan maupun dalam menjalankan kewajiban perpajakannya juga mempengaruhi keyakinan hakim untuk menolak gugatan wajib pajak. Dan yang terakhir adalah rasionalitas dari alasan yang dikemukakan oleh wajib pajak berpengaruh terhadap hasil putusan majelis hakim.

Tujuan dibentuknya lembaga peradilan adalah untuk mewujudkan keadilan dan kepastian hukum bagi pihak yang bersengketa. Pengadilan pajak sebagai pihak yudikatif memiliki peranan yang penting untuk melindungi kepentingan wajib pajak ketika terjadi sengketa pajak. Di dalam proses penyelesaian sengketa Pajak, pengetahuan dan pemahaman majelis terhadap ketentuan pajak dan pokok sengketa yang terjadi sangat dibutuhkan agar keputusan yang diterbitkan dapat memberikan keadilan bagi wajib pajak. Berdasarkan tinjauan yang telah dilaksanakan sebagaimana terdapat pada bab pembahasan, terdapat hal yang perlu dicermati terkait upaya pengadilan pajak dalam meberikan keadilan dan kepastian hukum kepada wajib pajak khususnya terkait sengketa yang diakibatkan karena kekhilafan wajib pajak. Hal tersebut adalah adanya misterpretasi majelis hakim di sebagian putusan dalam memahami substansi pokok sengketa pajak antara wajib pajak. Misinterpretasi majelis hakim adalah menurutnya kesesuaian pengenaan sanksi administrasi kepada wajib pajak terhadap ketentuan perpajakan meniadakan unsur sengketa pajak. Padahal jika dilihat berdasarkan substansi upaya hukum terhadap surat keputusan pengurangan atau penghapusasan sanksi administrasi yang diajukan wajib pajak, bahwa wajib pajak berharap agar sanksi administrasi tersebut dapat dihapuskan dikarenakan kesalahan wajib pajak disebabkan karena kekhilafan atau ketidaktahuan akan aturan. Adanya misinterpretasi membuat putusan menjadi tidak sesuai dengan pokok sengketa. Akibatnya kepentingan wajib pajak dalam hal memperoleh keadilan dan kepastian hukum terkait penyelesaian sengketa pajak menjadi tidak terpenuhi.

\section{DAFTAR PUSTAKA}

Dewi, A. K., \& Ma'ruf, U. (2019). Pelaksanaan Penelaahan Keberatan Terkait Pengajuan Pengurangan Atau Penghapusan Sanksi Administrasi Wajib Pajak Di Kantor Wilayah Direktorat Jenderal Pajak Jawa Tengah I. Seminar Nasional Mahasiswa Universitas Islam Sultan Agung, 14-26.

Harahap, Y. (1997). Beberapa Tinjauan Mengenai Sistem Peradilan Dan Penyelesaian Sengketa. Bandung: PT Citra Aditya Bhakti.

Huda, C. (2015, Oktober 12). Kekhilafan Dalam Pajak Dan Pidana. Dipetik Desember 15, 2020, dari http://huda-drchairulhudashmh.blogspot.com: http://hudadrchairulhudashmh.blogspot.com/2015/10/tinjauan-dari-aspek-hukumpidana.html?m=1

Krippendorff, K. (2004). Content Analysis: an Introduction to Its Methodology. London: SAGE Publications. 


\section{EDUCORETAX}

Volume 1 No. 1, Maret 2021

Liyana, N. F. (2019). Menakar Masalah dan Tantangan Administrasi Pajak: Kepatuhan Pajak di Era Self Assesment System. Pajak dan Keuangan Negara, 84-90.

Mustaqiem. (2014). Perpajakan Dalam Konteks Teori dan Hukum Pajak di Indonesia. Yogyakarta: Buku Litera Yogyakarta.

Myers, M. D. (2019). Qualitative research in business and management. California: Sage Publications Limited.

OECD. (1999). Principles of Good Tax Administration - Practice Note. Amsterdam: OECD.

Prabandari, A. I. (2020, November 2). Perbedaan Data Primer dan Sekunder dalam Penelitian, Ketahui Karakteristiknya. Dipetik Desember 15, 2020, dari Merdeka.com: https://www.merdeka.com/jateng/perbedaan-data-primer-dan-sekunder-daslampenelitian-ketahui-karakteristiknya-kln.html?page $=2$

Pudyatmoko, Y. S. (2020). Pengadilan dan Penyelesaian Sengketa di Bidang Pajak. Jakarta: PT Gramedia Pustaka Utama.

Rumadan, I. (2012). Eksistensi Pengadilan Pajak dalam Sistem Peradilan di Indonesia. Jurnal Hukum dan Peradilan, 36-62.

Sidharta. (2009). Moralitas Profesi Hukum. Bandung: Refika Aditama.

Siregar, H. (2015, Maret 23). Official Assesment Versus Self Assesment. Dipetik November 21, 2020, dari Medanbisnisdaily: https://www.medanbisnisdaily.com/news/read/2015/03/23/153595/official-assesmentversus-self-assesment/

Smith, A. (1904). Wealth of Nations. London: Mathuen \& Co., Ltd.

Strauss, j. (2015). Nonpayment of Taxes: When Ignorance of the Law Is An Excuse. Akron Law Journals, 611-633.

Sugiyono. (2010). Metode Penelitian Pendidikan Pendekatan Kuantitatif, Kualitatif, dan R\&D. Bandung: Alfabeta.

Tarjo, \& Kusumawati, I. (2006). Analisis Perilaku Wajib Pajak Orang Pribadi Terhadap Pelaksanaan Self Assesment System: Suatu Studi di Bangkalan. JAAI, 101-120.

Thomas, R. D. (2006). A General Inductive Approach for Analyzing Qualitative Evaluation Data. American Journal of Evaluation, 237-242.

Wahyudi, T. H. (2020). Keberadaan dan Peran Pengadilan Pajak dalam Memberikan Keadilan Substantif Kepada Wajib Pajak. SELISIK, 72-85.

Winings, M. C. (1993). Ignorance is Bliss, Especially for the Tax Evader. Journal of Criminal Law and Criminology, 575-603.

Setiawan, B., \& Cahyady, Y. (2020). Upaya Hukum Pajak : Mengenal Upaya Hukum Perpajakan dan Hukum Acaranya. Tangerang Selatan: Politeknik Keuangan Negara STAN.

Widiastuti, D. (2015). Eksistensi Pengadilan Pajak dalam Sistem Peradilan di Indonesia. Retrieved Juli 06, 2021, from www.ptun-semarang.go.id: http://www.ptunsemarang.go.id/artikel/147-eksistensi-pengadilan-pajak-dalam-sistem-jurnal-ma.html

Indonesia. 2009. Undang-Undang Republik Indonesia Nomor 16 Tahun 2009 tentang Perubahan Keempat atas Undang-Undang Nomor 6 tahun 1983 tentang Ketentuan Umum dan Tata Cara Perpajakan. Lembaran Negara RI tahun 2009 No. 62. Jakarta: Sekretariat Negara

Indonesia. 2000. Undang-Undang Republik Indonesia Nomor 16 Tahun 2000 tentang Perubahan Kedua atas Undang-Undang Nomor 6 tahun 1983 tentang Ketentuan Umum dan Tata Cara Perpajakan. Lembaran Negara RI tahun 2000 No. 126. Jakarta: Sekretariat Negara 


\section{EDUCORETAX}

Volume 1 No. 1, Maret 2021

Indonesia. 2002. Undang-Undang Republik Indonesia Nomor 14 Tahun 2002 tentang Pengadilan Pajak. Lembaran Negara RI tahun 2002 No. 27. Jakarta: Sekretariat Negara

Indonesia. 2009. Undang-Undang Republik Indonesia Nomor 48 Tahun 2009 tentang Kekuasaan Kehakiman. Lembaran Negara RI tahun 2009 No. 157. Jakarta: Sekretariat Negara

Indonesia. 2009. Undang-Undang Republik Indonesia Nomor 51 Tahun 2009 tentang Perubahan Kedua atas Undang-Undang Nomor 5 Tahun 1985 tentang Peradilan Tata Usaha Negara. Lembaran Negara RI tahun 2009 No. 160. Jakarta: Sekretariat Negara

Indonesia. 2011. Peraturan Pemerintah Nomor 74 Tahun 2011 tentang Tata Cara Pelaksanaan Hak dan Pemenuhan Kewajiban Perpajakan. Lembaran Negara RI tahun 2011 No. 162. Jakarta: Sekretariat Negara

Kementerian Keuangan. 2013. Peraturan Menteri Keuangan Nomor 8/PMK.03/2013 tentang Tata Cara Pengurangan atau Penghapusan Sanksi Administrasi dan Pengurangan atau Pembatalan Surat Ketetapan Pajak atau Surat Tagihan Pajak. Berita Negara RI tahun 2013 No. 11. Jakarta: Sekretariat Negara

Mahkamah Agung. 2018. Peraturan Mahkamah Agung Nomor 6 Tahun 2018 tentang Pedoman Penyelesaian Sengketa Administrasi Pemerintahan Setelah Menempuh Upaya Administrasi. Berita Negara RI tahun 2018 No. 1586. Jakarta: Sekretariat Negara 